\title{
RAZGLEDI
}

\section{GEOGRAFSKA DEDIŠČINA - SEDEM DESETLETIJ ZEMLJEPISNEGA MUZEJA}

\author{
AVTORJA
}

\section{dr. Matija Zorn}

Znanstvenoraziskovalni center Slovenske akademije znanosti in umetnosti, Geografski inštitut Antona Melika, Gosposka ulica 13, SI - 1000 Ljubljana, Slovenija

matija.zorn@zrc-sazu.si

\section{dr. Primož Gašperič}

Znanstvenoraziskovalni center Slovenske akademije znanosti in umetnosti, Geografski inštitut Antona Melika, Gosposka ulica 13, SI - 1000 Ljubljana, Slovenija

primoz.gasperic@zrc-sazu.si

DOI: $10.3986 / G V 88106$

UDK: 069:91(497.4)

COBISS: 1.02

\section{IZVLEČEK}

\section{Geografska dediščina - sedem desetletij Zemljepisnega muzeja}

Leta 2016 mineva sedemdeset let od ustanovitve Zemljepisnega muzeja Geografskega inštituta Antona Melika ZRC SAZU. Ustanovljen je bil 7. maja 1946. Muzej pridobiva, hrani ter ureja kartografsko, slikovno in arhivsko geografsko gradivo ter pripravlja razstave. Obsega sedem zbirk - zbirko zemljevidov, zbirko atlasov, zbirko globusov, zbirko slik, zbirko knjižnih del, zbirko kartografskih in geografskih pripomočkov ter zbirko statističnih podatkov. S hranjenjem, razstavljanjem in raziskovanjem tega gradiva sodi med najpomembnejše ohranjevalce slovenske geografske dediščine.

\section{KLJUČNE BESEDE}

geografija, kulturna dediščina, geografska dediščina, zgodovinski viri, Zemljepisni muzej

\section{ABSTRACT}

\section{Geographical heritage: seven decades of the Geographical Museum}

The year 2016 marks seven decades since the founding of the Geographical Museum at the Anton Melik Geographical Institute of the Research Centre of the Slovenian Academy of Sciences and Arts. It was established on May 7th, 1946. The museum receives, stores, and organizes cartographic, pictorial, and archival geographic material, prepares exhibitions, and also promotes the popularization of geography. It comprises seven collections: maps, atlases, globes, pictures, books, cartographic and geographic instruments, and statistical data. By keeping this kind of material, it is an important preserver of Slovenian geographical heritage.

\section{KEY WORDS}

geography, cultural heritage, geographical heritage, historical sources, Geographical museum

Uredništvo je prispevek prejelo 5. oktobra 2016. 


\section{Uvod}

Leta 2016 mineva sedemdeset let od ustanovitve Zemljepisnega muzeja Geografskega inštituta Antona Melika ZRC SAZU. Muzej je 7. maja 1946 na pobudo akademika Antona Melika pod nazivom Zemljepisni muzej Slovenije ustanovila Vlada Ljudske republike Slovenije (Uredba ... 1946, 202-203; slika 1). Do leta 1962 je deloval samostojno, potem je bil priključen novonastalemu Inštitutu za geografijo Univerze v Ljubljani (Perko 2012, 4), dokler ni 1. septembra 2002 prišel pod okrilje Geografskega inštituta Antona Melika ZRC SAZU (Gašperič in Zorn 2015). Uvrščamo ga med "posebne muzeje« oziroma tiste, ki »... opravljajo muzejsko dejavnost za posebno strokovno področje ...« (Zgodovina ... 2016).

Od njegove ustanovitve so muzej vodili oziroma v njem delovali: Vladimir Leban (1946-1962) (Vrišer 1992a, 113), Mirko Bogić (1962-1976) (medmrežje 1), Milena Pak (1976-1981), Bibijana Mihevc (1982-2002) (Potrdilo ... 2004) ter Primož Gašperič (2003-).

Z visoko obletnico se Zemljepisni muzej pridružuje častitljivim obletnicam, ki so jih slovenske geografske inštitucije in revije praznovale v zadnjih letih: 90-letnica ustanovitve Oddelka za geografijo Filozofske fakultete Univerze v Ljubljani leta 2009 (Resnik Planinc in Kušar 2010), 70-letnica ustanovitve Geografskega inštituta Antona Melika ZRC SAZU leta 2016 (Perko in Zorn 2016), 60 let preučevanja krasa na Inštitutu za raziskovanje krasa ZRC SAZU leta 2007 (Prelovšek 2007), 50-letnica

Slika 1: Uredba vlade Ljudske republike Slovenije o ustanovitvi Zemljepisnega muzeja Slovenije 7. maja 1946 (Uredba ... 1946, 202-203).

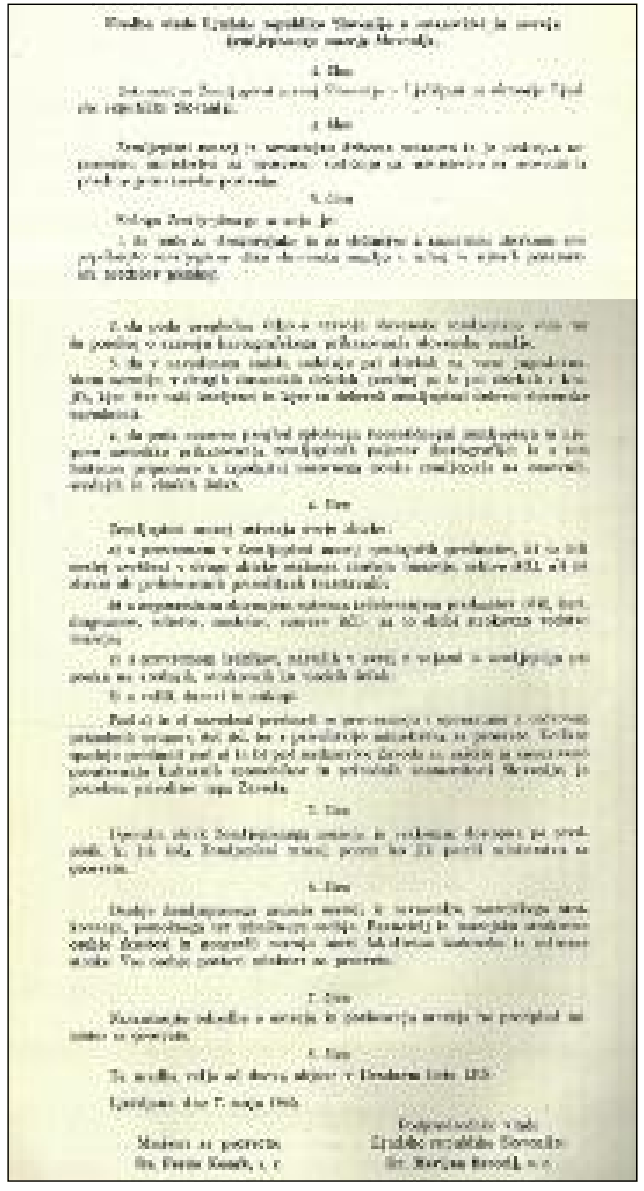


poučevanja geografije na Univerzi v Mariboru leta 2011 (Horvat 2013), 15-letnica Oddelka za geografijo Fakultete za humanistične študije Univerze na Primorskem leta 2016 (Brečko Grubar, Koderman in Kovačič 2016), osemdeseti letnik revije Geografski vestnik leta 2008 (Perko in Zorn 2008), šestdeseti letnik revije Geografski obzornik leta 2013 (Kušar 2013), petdeseti letnik revije Acta geographica Slovenica leta 2010 (Zorn in Komac 2010) ter 60 let revije Acta Carsologica leta 2015 (Gabrovšek in Ravbar 2015).

Posebni geografski oziroma zemljepisni muzeji so se začeli pojavljati v prvi polovici 20. stoletja. Eden prvih je bil ustanovljen leta 1919 v Sovjetski zvezi v današnjem Sankt Peterburgu (Semenov 1926, 642), približno desetletje kasneje je bil ustanovljen še v Nemčiji v Leipzigu (Reinhard 1934). Med nam bližjimi velja omeniti Madžarski geografski muzej (Magyar Földrajzi Múzeum) iz Budimpešte (Hungarian ... 2016). Pred tem so bile bogate kartografske zbirke večinoma del večjih nacionalnih muzejev in knjižnic, kar velja še danes. Največjo tovrstno zbirko ima knjižnica Library of Congress iz Washingtona, ki hrani prek 5,5 milijona zemljevidov, 80.000 atlasov in 500 globusov (Collections ... 2006). Za geografko dediščino so pomembni tudi »... številni univerzitetni muzeji, povezani zoddelki za geografijo (na primer Birmingham, Cambridge in Glasgow) ... "(Geoghegan 2010, 1467), kot tudi zbirke združenj, na primer britanske Royal Geographical Society (Geoghegan 2010, 1467) in ameriške National Geographic Society (National ... 2016). Prva hrani prek dva milijona enot zgodovinskega geografskega gradiva (About ... 2016). Med tem gradivom je okrog milijon zemljevidov in načrtov, 3000 atlasov in 40 globusov. Najstarejše kartografsko gradivo je s konca 15. stoletja (Maps ... 2016). Potem pa so tu še bolj specializirani muzeji, ki predstavljajo posamezen element geografske dediščine, na primer Globenmuseum/Globe Museum (Muzej globusov; slika 2) Avstrijske nacionalne knjižnice na Dunaju, ki ima največjo javno dostopno zbirko globusov na svetu s prek 660 hranjenimi primerki (Mokre 2005, 6, 53; Globenmuseum 2016).

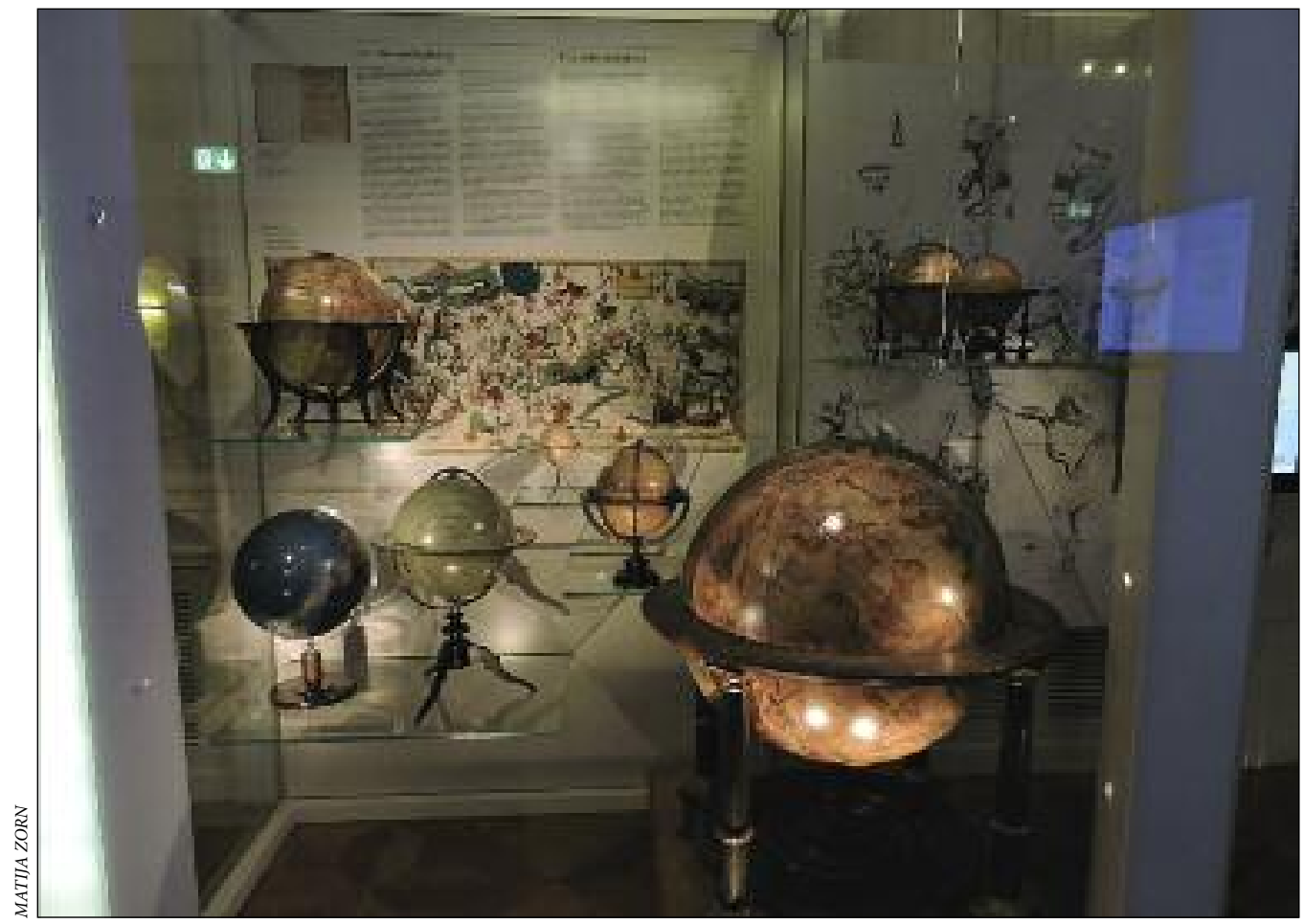

Slika 2: Muzej globusov Avstrijske nacionalne knjižnice na Dunaju. 
»Geografskost« je prisotna tudi v drugih muzejih, saj so imeli številni že v drugi polovici 19. stoletja svoje zbirke predstavljene po geografskih območjih (na primer Smithsonian v Washingtonu ali British Museum v Londonu) (Naylor in Hill 2011, 73-74).

\section{Geografska dediščina}

Zemljepisni muzej je danes posebna enota Geografskega inštituta Antona Melika ZRC SAZU, ki pridobiva, hrani, ureja ter raziskuje kartografsko, slikovno in arhivsko geografsko gradivo ter pripravlja razstave. $V$ tem se njegovo poslanstvo ni spremenilo od ustanovitve in zavoljo tega sodi med najpomembnejše ohranjevalce geografske dediščine. Pod pojmom geografska dediščina, ki jo hrani Zemljepisni muzej, razumemo pisne (tudi kartografske; Vrišer1992b, 114) in materialne vire, ki so nastajali z razvojem geografske stroke in sodijo med premično kulturno dediščino.

Premična kulturna dediščina so »... posamezni predmeti ali skupine predmetov, nastali kot rezultat ustvarjalnosti človeka in njegovih različnih dejavnosti, družbenega razvoja in dogajanj, značilnih za posamezna obdobja. Premična kulturna dediščina, ki jo hranijo muzeji, arhivi in knjižnice je z zakonom razglašena za spomenik ..." (Erhartič 2014, 29; medmrežje 2).

V muzeju je združenih sedem zbirk. Zbirka zemljevidov obsega zemljevide različnih vsebin in meril od 16. stoletja do sodobnosti (preglednica 1). Večina gradiva se nanaša na slovensko ozemlje in sosednje dežele. Zbirka slik obsega razglednice in fotografije slovenskih krajev in pokrajin ter manjše število bakrotiskov. Zbirka atlasov (sliki 3 in 4) obsega številne redke primerke najbolj znanih svetovnih avtorjev in odseva razvoj upodobitev sveta, zbirka globusov pa globuse različnih dimenzij in starosti ter prikaze ozvezdij (slika 5). Zbirka knjižnih del obsega publikacije, povezane z geografsko, kartografsko in zgodovinsko tematiko (sliki 6 in 7). Zbirka kartografskih in geografskih pripomočkov hrani

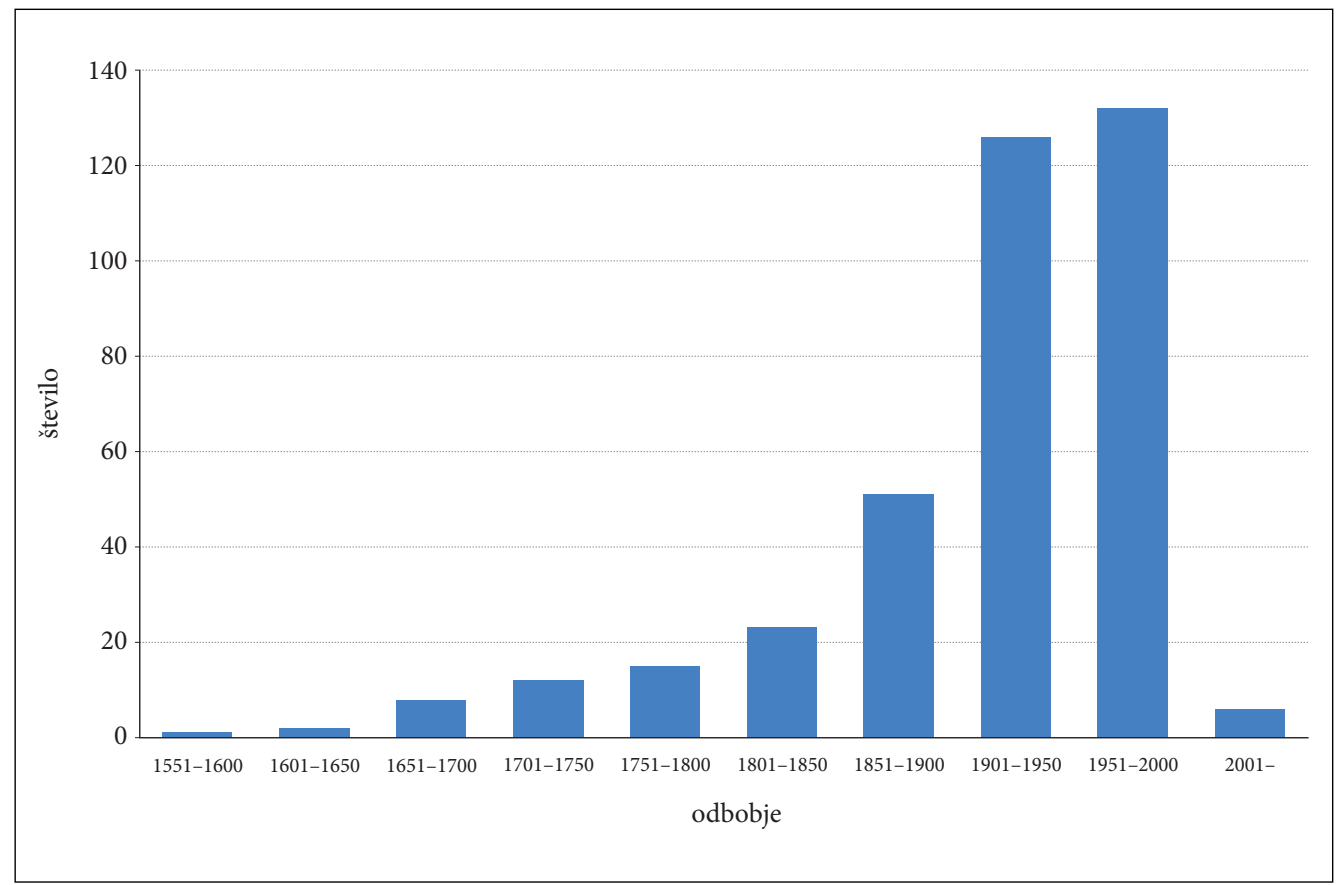

Slika 3: Število hranjenih atlasov po petdesetletnih obdobjih. Zemljepisni muzej hrani skupaj 376 atlasov. 
Preglednica 1: Tematska razdelitev zemljevidov $v$ zbirki zemljevidov zajema 2662 enot. V preglednici niso zajeti zemljevidi iz zbirke atlasov, stenski zemljevidi ter topografski zemljevidi večjih meril iz 20. stoletja.

tematska razdelitev zemljevidov število

slovensko ozemlje od 16. do 18. stoletja

$\begin{array}{ll}\text { Kranjska } & 50\end{array}$

$\begin{array}{lr}\text { Štajerska } & 29\end{array}$

Koroška

načrti, turistični in prometni zemljevidi $\quad 757$

$\begin{array}{ll}\text { katastrski načrti in podrobne skice } & 19\end{array}$

načrti mest in okolice (Slovenija in Jugoslavija) $\quad 70$

$\begin{array}{lr}\text { načrti mest in okolice (drugo) } & 130\end{array}$

$\begin{array}{ll}\text { turistični zemljevidi } & 136\end{array}$

Ljubljana in okolica $\quad 182$

$\begin{array}{ll}\text { zemljevidi prometnih povezav } & 122\end{array}$

pomorski zemljevidi 98

slovensko ozemlje in ozemlje Jugoslavije v 19. in 20. stoletju 1041

Habsburška monarhija $\quad 89$

Kraljestvo Ilirija $\quad 11$

Kraljevina SHS in Kraljevina Jugoslavija $\quad 54$

Dravska banovina $\quad 17$

zemljevidi Alojzija Knafelca in Rudolfa Badjure $\quad 35$

$\begin{array}{ll}\text { Rapalska meja } & 71 \\ & \end{array}$

SFR Jugoslavija $\quad 55$

upravna razdelitev Slovenije $\quad 42$

pregledni zemljevidi Slovenije $\quad 161$

deli slovenskega ozemlje in zamejstva $\quad 182$

tematski naravnogeografski zemljevidi Slovenije $\quad 121$

tematski družbenogeografski zemljevidi Slovenije $\quad 131$

$\begin{array}{ll}\text { tematski zemljevidi Jugoslavije } & 72\end{array}$

\begin{tabular}{lr}
\hline posamezni zemljevidi iz nepopolnih atlasov & $\mathbf{1 3 0}$ \\
\hline po celinah & $\mathbf{5 2 8}$ \\
Evropa (srednje in majhno merilo; brez Habsburške monarhije in Jugoslavije) & 243 \\
Evropa (večje merilo) & 106 \\
Azija & 84 \\
Avstralija & 4 \\
Amerika & 30 \\
Afrika & 51 \\
svet & 10 \\
\hline drugi zemljevidi & $\mathbf{1 1 4}$ \\
reliefni zemljevidi in panorame & 22 \\
tematski družbenogeografski zemljevidi izven Slovenije & 36 \\
tehnološki postopki tiska & 56 \\
\hline
\end{tabular}




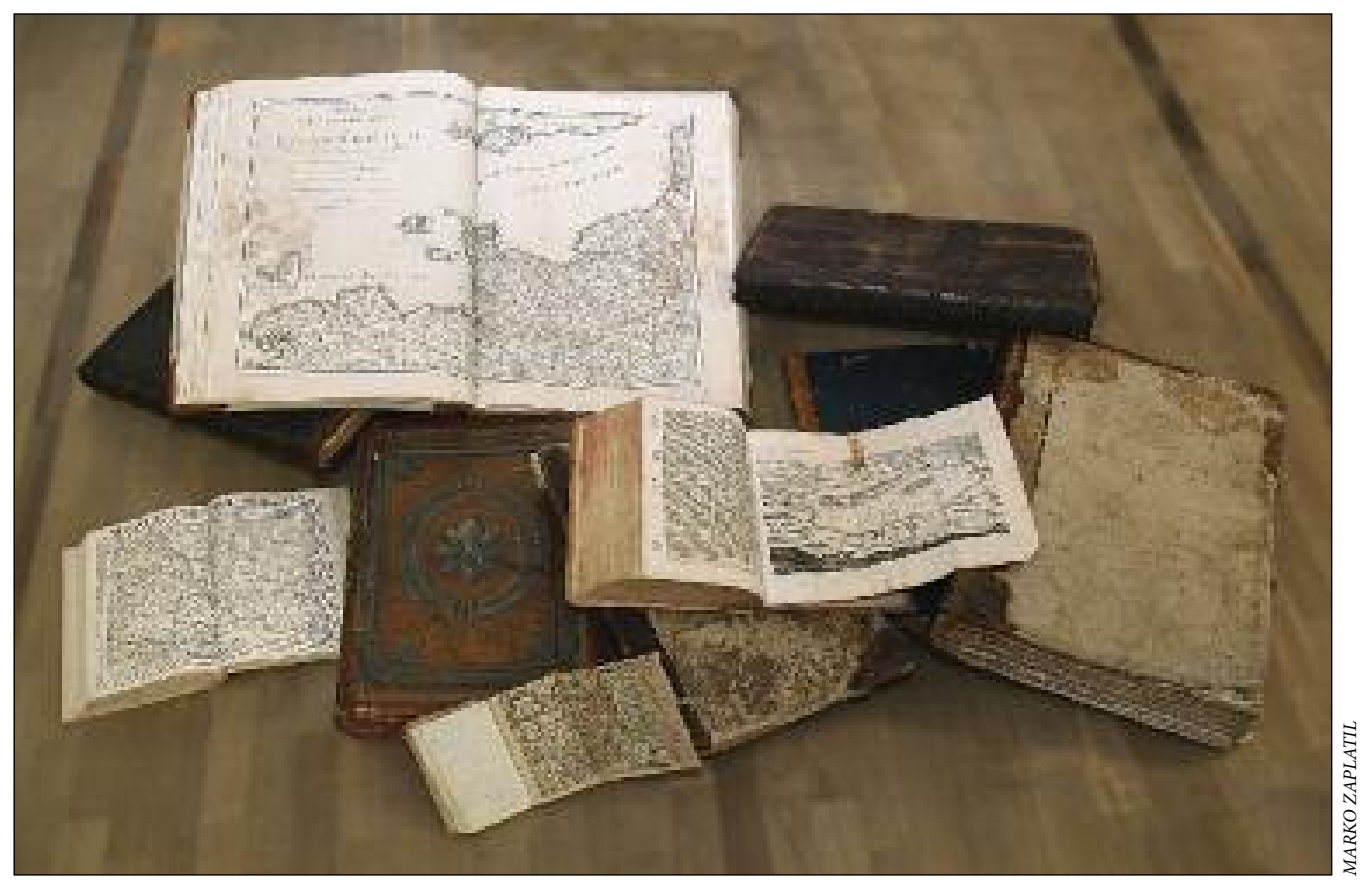

Slika 4: Nekateri stari atlasi in zgodovinske knjige, ki jih hrani Zemljepisni muzej.

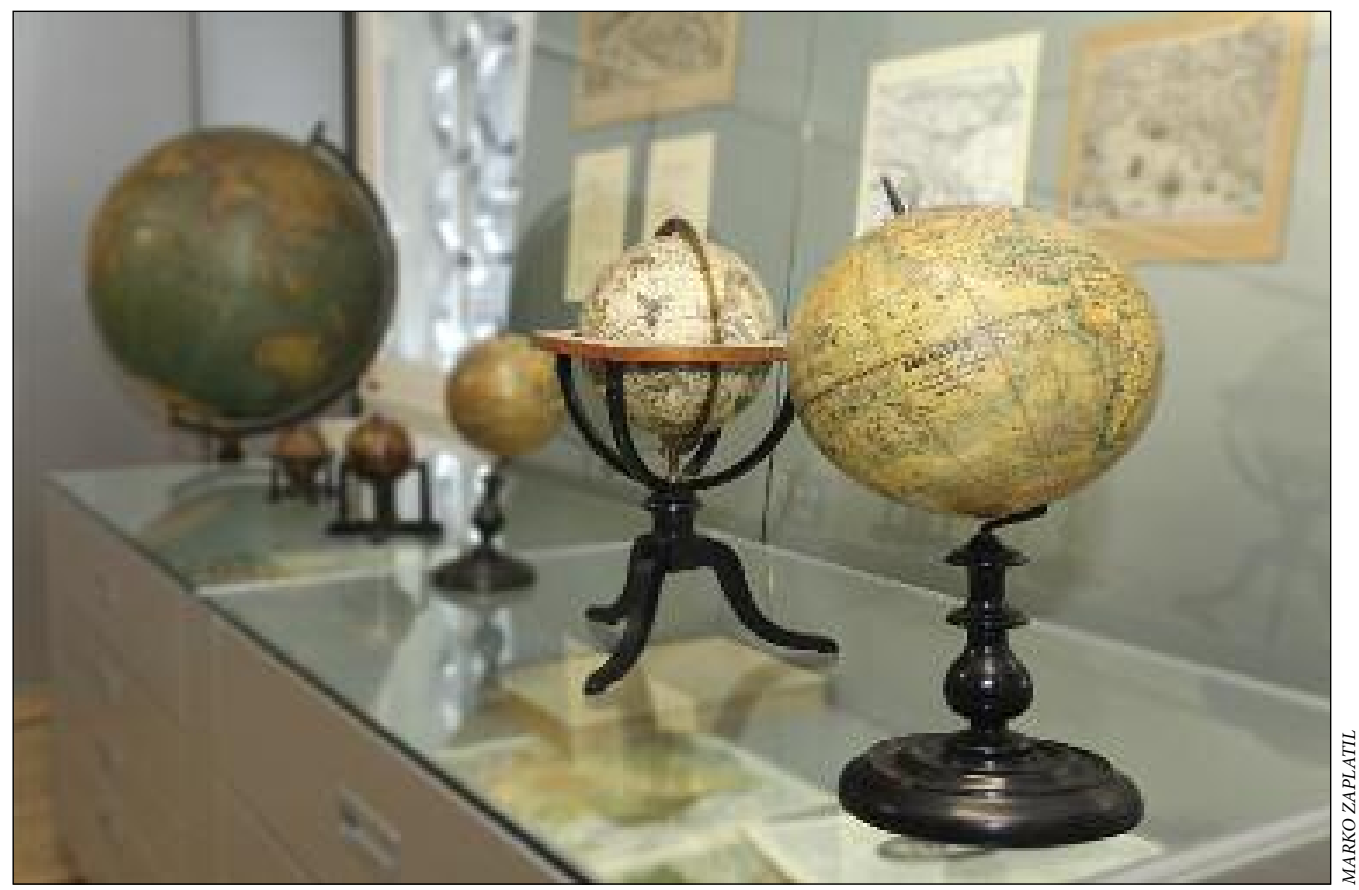

Slika 5: Zbirka globusov. 


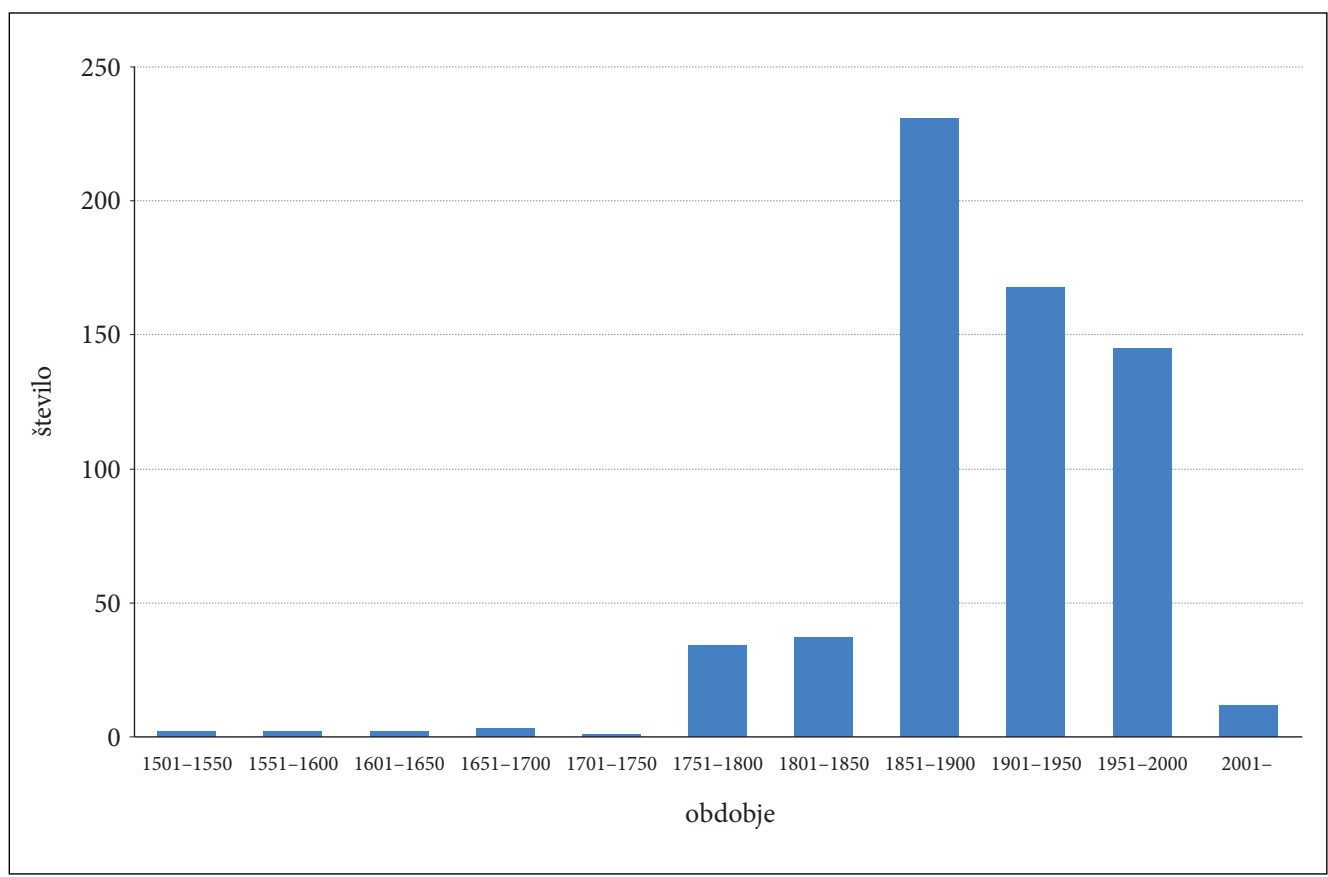

Slika 6: Zbirka knjižnih del v Zemljepisnem muzeju po petdesetletnih obdobjih.

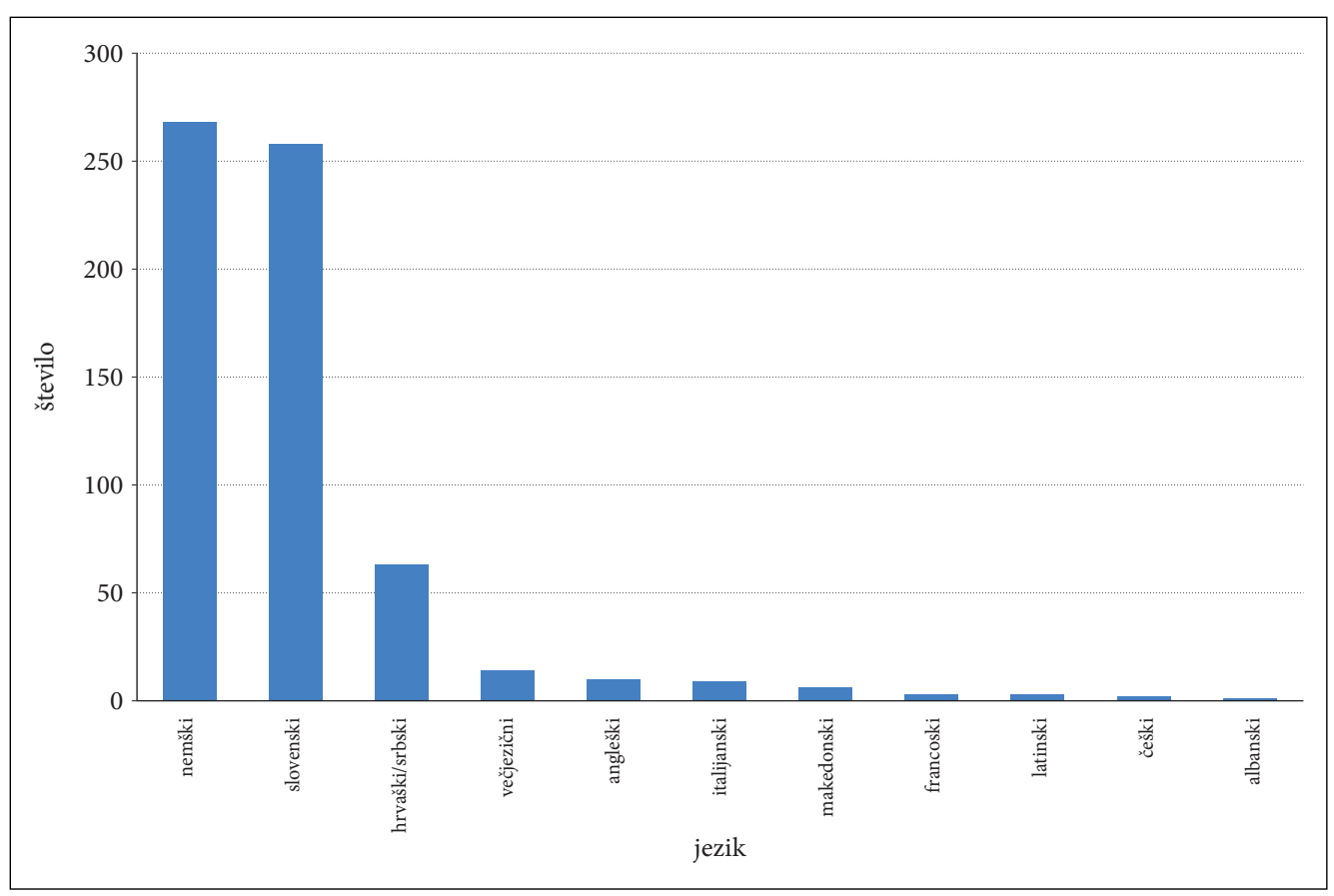

Slika 7: Jezikovna sestava publikacij v zbirki knjižnih del Zemljepisnega muzeja. 


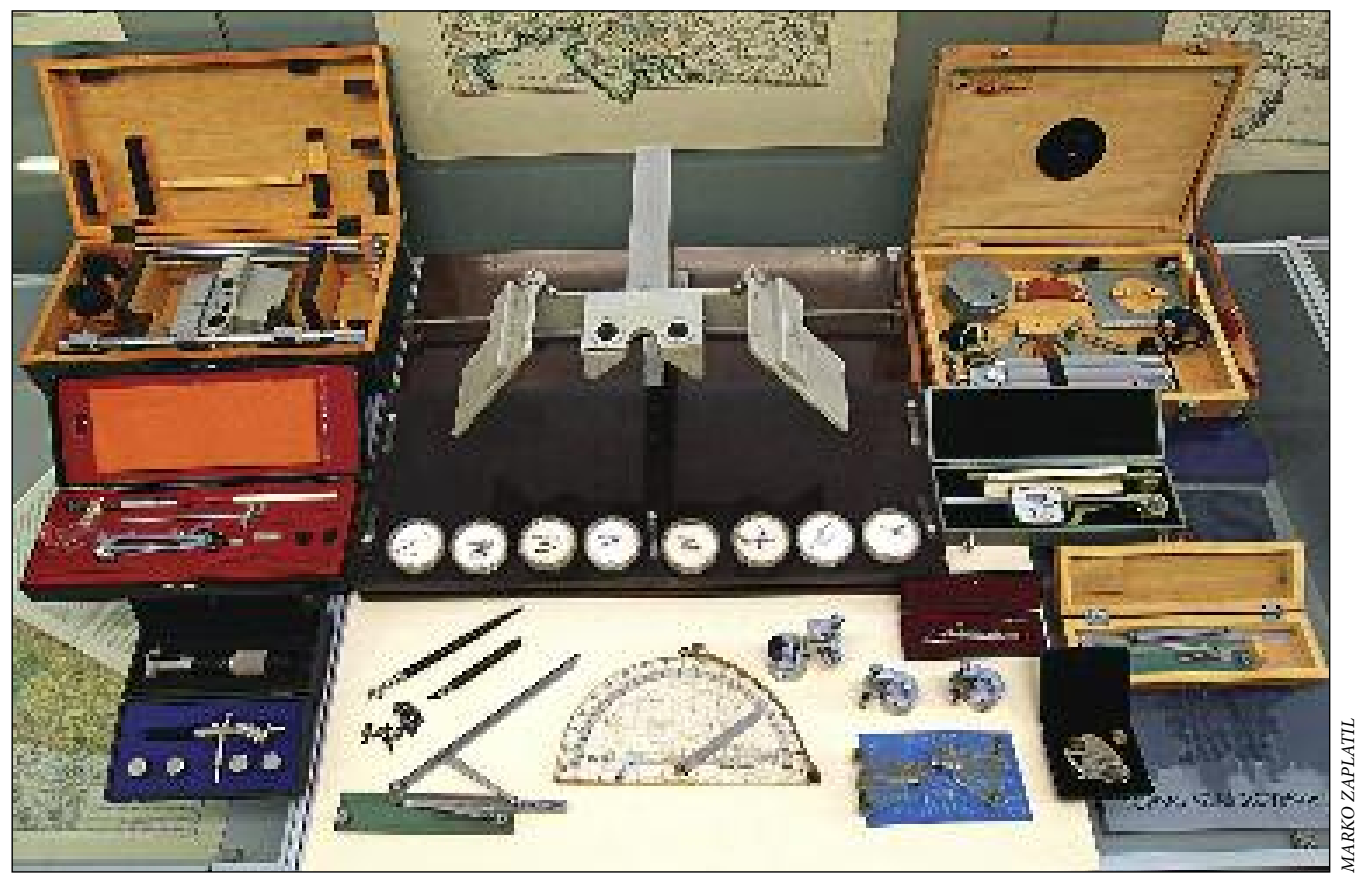

Slika 8: Del zbirke kartografskih pripomočkov.

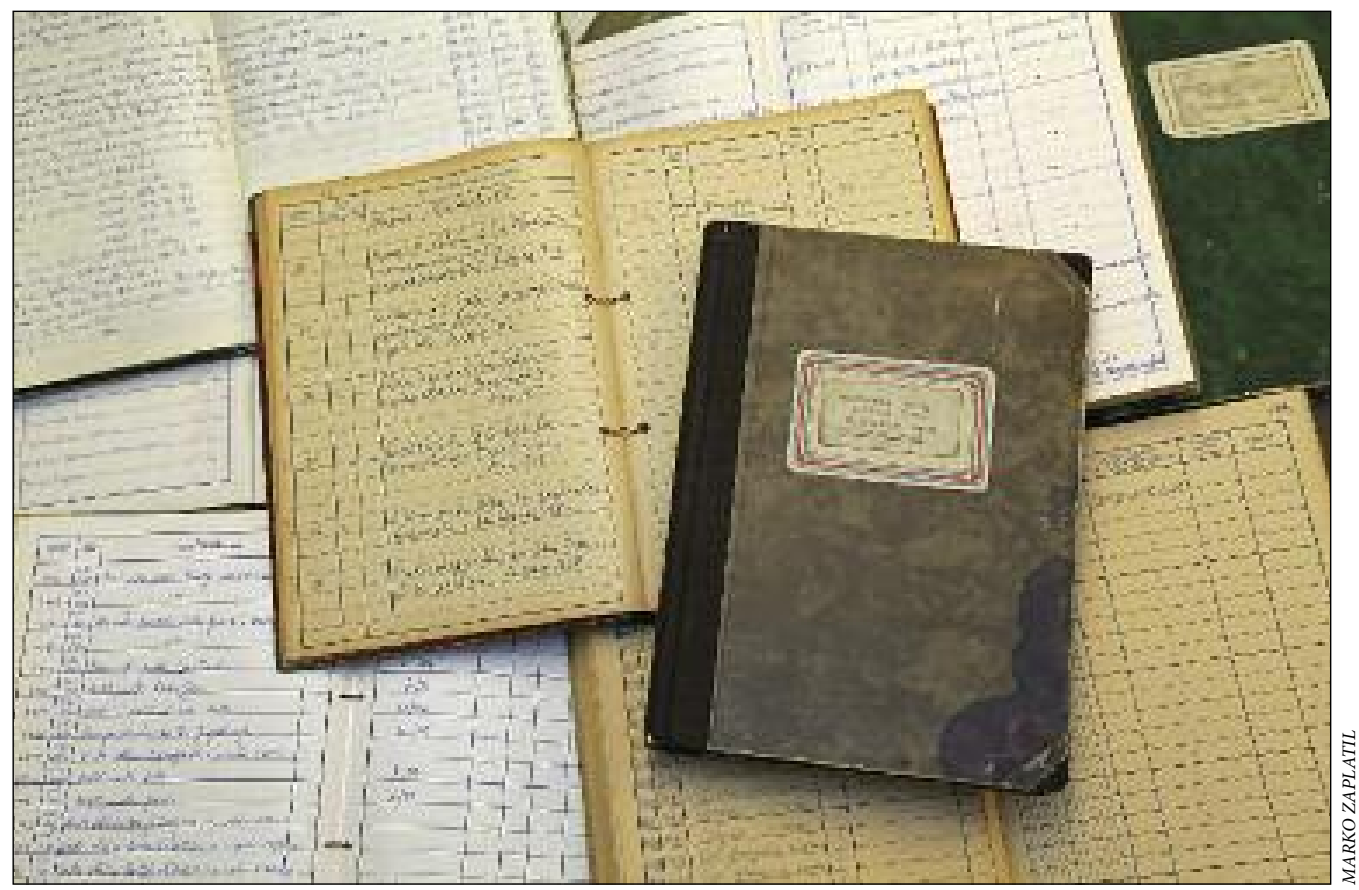

Slika 9: Starejše knjige za popis gradiva v Zemljepisnem muzeju. 
orodja (slika 8), ki so jih kartografi in geografi uporabljali za izdelovanje »klasičnih « zemljevidov pred uveljavitvijo digitalne kartografije ter geografske terenske pripomočke. Zbirka statističnih podatkov obsega statistično gradivo o Sloveniji. V preteklosti se je gradivo vpisovalo ročno v popisne knjige (slika 9), danes pa se sledi univerzalnim bibliografskim standardom in tehnološkemu razvoju.

Zemljepisni muzej seveda ni edini, ki hrani slovensko geografsko dediščino. Predvsem zbirka zemljevidov se dopolnjuje s Kartografsko in slikovno zbirko Narodne in univerzitetne knjižnice v Ljubljani, kjer prav tako hranijo številna kartografska dela od 16. stoletja naprej (medmrežje 3; Šolar 2007, 72). Ustanovljena je bila leta 1945, a je prevzela fond, ki se je začel zbirati že leta 1774 z ustanovitvijo knjižnice pri ljubljanskem liceju (Vobovnik-Avsenak 1990, 54). Danes imajo v hrambi prek 24.000 zemljevidov in več kot 2100 atlasov (Šolar 2016b).

Bogato kartografsko zbirko s tradicijo od dvajsetih let prejšnjega stoletja ter $\mathrm{z}$ deli od druge polovice 19. stoletja naprej ima Oddelek za geografijo Filozofske fakultete Univerze v Ljubljani (Frelih in ostali 2009, 136, 142). Skupaj hrani 39.556 enot kartografskega gradiva in 530 atlasov (Knez Račič 2016).

Zgodovinsko kartografsko gradivo hranijo tudi druge knjižnice, arhivi in muzeji (Mihevc 1992, 4). Univerzitetna knjižnica Maribor je leta 2012 v kartografski zbirki hranila blizu 9500 enot zemljevidov in atlasov (medmrežje 4). Omeniti velja kartografsko zbirko v piranskem Pomorskem muzeju »Sergej Mašera«, ki hrani blizu tisoč predvsem pomorskih zemljevidov (Gaberc 1999, 16). Posebej pomembna je hramba več zemljevidov iz prve polovice 16. stoletja (Markovič 1995; Terčon 2001, 58).

Danes je za javno dostopnost pisnih in kartografih virov pomembna Digitalna knjižnica Slovenije (dLib.si). V okviru te je dostopna tudi "geoknjižnica" oziroma spletno dostopno zgodovinsko kartografsko gradivo. Na spletnem mestu Digitalne knjižnice Slovenije »... največji del uporabnikov iz tujine poizveduje prav po kartografskem gradivu ...« (Žagar in ostali 2010, 30). Iz zbirke Narodne in univerzitetne knjižnice je dostopnih prek dvesto enot zgodovinskega kartografskega gradiva, več deset enot pa tudi iz zbirk drugih knjižnic (na primer Knjižnica Mirana Jarca Novo mesto, Osrednje knjižnica Celje, Osrednja knjižnica Srečka Vilharja Koper) (Digitalna ... 2016). Digitalizacije je zelo pomembna pri ohranjanju geografske dediščine, saj se z njo prepreči možnost njenega poškodovanja ter hkrati olajša dostopnost gradiva.

Med arhivi izpostavljamo Arhiv Republike Slovenije, ki hrani zemljevide zemljiškega katarska iz 19. stoletja (Triglav 2009), ki so deloma (franciscejski kataster) dostopni na medmrežju (Register ... 2016).

Zgodovinsko kartografsko gradivo, ki se navezuje na naše ozemlje, najdemo tudi na tujih spletiščih. Med pomembnejšimi je Mapire (Historical... 2016), ki omogoča georeferencirano pregledovanje zemljevidov Prve (jožefinski vojaški zemljevid; druga polovica 18. stoletja), Druge (prva polovica 19. stoletja) in Tretje (druga polovica 19. stoletja) vojaške izmere Habsburške monarhije. Kartografsko gradivo o slovenskem ozemlju najdemo tudi pri verjetno največjem spletnem ponudniku zgodovinskega kartografskega gradiva Old Maps Online (2016), ki ima indeksiranih prek 400.000 zemljevidov. Za kartografsko dediščino je pomembna spletna stran CartoMundi (2016), ki z enotnim katalogom olajša iskanje razpršenih informacij (Šolar 2016a, 92).

Digitaliziranega kartografskega gradiva slovenske geografske inštitucije (še) nimajo dostopnega na medmrežju, zato pa so v digitalni obliki že dostopni vsi starejši letniki revij Geografski vestnik (1925-; Zorn in Ciglič 2014, 9), Geografski zbornik (1952-2002), Geographica Slovenica (1971-2002) in Dela (1985-).

\section{Pomen kartografskih virov}

Zgodovinski dogodki in prostor, kjer so se dogajali, so nerazdružljivo povezani. Zgodovinske dogodke je lahko "pospešila « neka pokrajina ali pa so ti vplivali na njen nadaljnji razvoj oziroma spremembe v njej (Slukan Altić 2003, 21). „Zemljepisno okolje je za zgodovinarja toliko pomembnejše, ker je to brez dvoma eden med pomembnimi činitelji v zgodovinskem razvoju samem "(Grafenauer 1960, 284). Zato 
je toliko bolj presenetljivo, da zgodovinarji razmeroma redko uporabljajo kartografske vire (Jenny, Jenny in Hurni 2009, 129), ki so prvovrstni vir za prostorsko razumevanje pokrajine v nekem obdobju oziroma za spremljanje prostorske dinamike skozi daljša obdobja. Grafenauer $(1960,288)$ na primer zgodovinske zemljevide le bežno omeni pri razlagi zgodovinske geografije kot pomožne vede zgodovine, a ne kot vir zgodovinskih podatkov, pač pa kot način podajanja rezultatov. To se je do danes spremenilo, saj se zgodovinsko kartografsko gradivo vse pogosteje uporablja kot vir geografskim in zgodovinskim raziskavam (Jenny in Hurni 2011, 402).

Uporabnost zgodovinskega kartografskega vira (na primer jožefinski vojaški zemljevid) za geografijo oziroma pokrajinske raziskave je bila v Geografskem vestniku že predstavljena (Zorn 2007; Štular 2010), kot tudi način georeferenciranja takšnih virov (na primer franciscejski kataster; Petek in Fridl 2004).

Kartografski viri niso le sredstvo za prostorski prikaz pojavov, pač pa so verodostojen dokument prostora, časa in družbenih razmer, v katerem so nastali (Slukan Altić 2003, 21,23). Zato jih lahko obravnavamo kot vire prve roke, pri katerih "... je mogoče ugotoviti neposreden stik avtorja vira $z$ dogodki ali stanji ..." (Grafenauer 1960, 252). Pogosto vsebujejo informacije, ki niso zabeležene v nobenem drugem viru (na primer zemljepisna imena, potek meja, prometnic, vodotokov, oblik površja) (Rumsey in Williams 2002, 1).

Kot vir se pretežno uporabljajo pri zgodovinski geografiji in okoljski zgodovini (Slukan Altić 2003, 21), predvsem v povezavi s spremembami rabe tal (na primer Petek, Bric in Rotar 2004; Frajer in Geletič 2011; Fuchs in ostali 2015) in kulturne pokrajine (na primer Petek in Urbanc 2004).

Njihovo uporabo za kvantitativno preučevanje pokrajinskih sprememb so pospešili geografski informacijski sistemi (GIS-i), ki so jih »... osvobodili statičnosti ... « oziroma le odtisa na papirju. Pred uporabo GIS-ov je bila njihova uporaba »analogna « oziroma se je kartografske vire med seboj primerjalo subjektivno, s »kritičnim očesom « bralca. Rezultati so bili tako zelo odvisni od njegovih interpretacijskih sposobnosti. Pri uporabi GIS-ov so kartografski viri spremenjeni v digitalno obliko, kar omogoča objektivno kombiniranje $\mathrm{z}$ drugimi prostorskimi podatki (Rumsey in Williams 2002, 3; Jenny, Jenny in Hurni 2009, 129).

Kot pri vseh zgodovinskih virih je tudi pri kartografskih nujna kritična obravnava. V povezavi s tem je treba poznati zgodovinski kontekst, v katerem so nastali, saj so odraz potreb naročnikov (Jenny, Jenny in Hurni 2009, 130-131), kar je vplivalo na vsebino. Pomembno je, ali je kartografsko gradivo nastalo kot plod terenskega dela kartografa (in je kot tako vir prve roke), ali so bile za izdelavo uporabljene že obstoječe kartografske podlage (in je kot tako vir druge roke), ki zato lahko prinašajo zastarele podatke. Takšen primer je izdaja antične Ptolemajeve Geografije Sebastiana Münstra iz leta 1552, ki jo hranimo v muzeju (slika 10). Nenazadnje sta pomembna tudi avtorstvo, saj so kartografi pripadali različnim »šolam «, ter tehnološki razvoj kartografskih tehnik, kar se kaže v njihovi natančnosti. Zavedati se moramo tudi, da ima lahko kartografski vir načrtne napake (na primer vojaški zemljevidi) ali napake, povezane z nepoznavanjem pokrajine (Rumsey in Williams 2002, 1; Slukan Altić 2003, 23; Jenny, Jenny in Hurni 2009, 133; Gašperič 2016a, 36), kar se pri številnih tujih avtorjih, ki prikazujejo slovensko ozemlje, kaže na primer pri močno prevelikem Cerkniškem jezeru (Gašperič 2007; 2016).

\section{Pomembnejša kartografska dela v hrambi}

Med pomembnejšimi kartografskimi deli slovenskega ozemlja (Mihevc 1993; 1998; Gašperič 2007), ki jih hrani Zemljepisni muzej, so:

- Münstrova izdaje 'Ptolemajeve Geografije' iz leta 1552. Gre za razsvetljensko različico dela Geografija (Geographike hyphegesis) grškega geografa Klavdija Ptolemaja iz 2. stoletja. Izvirnik je bil sestavljen iz osmih knjig. Prvih sedem je obravnavalo splošna načela kartografije in metode kartografske projekcije, navodila za sestavljanje zemljevidov ter podatke o geografski legi krajev, rek in podobno. V osmi knjigi so bili zbrani zemljevidi takrat znanega sveta. Nemški kartograf Sebastian Münster je delo ponovno izdal in mu dodal sodobnejše zemljevide iz srede 16. stoletja (slika 10). 


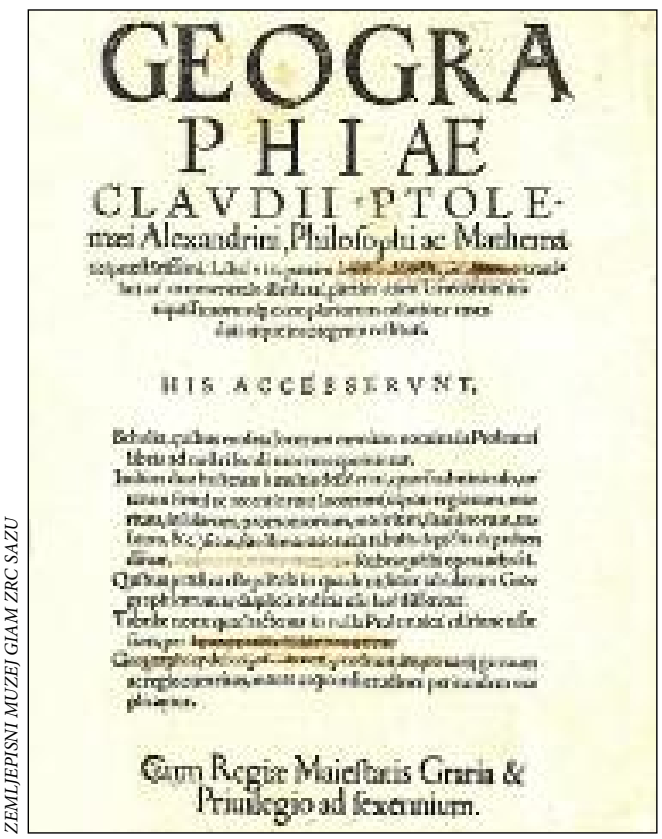

Slika 10: Naslovna stran priredbe Ptolemajeve Geografije Sebastiana Münstra iz leta 1552.

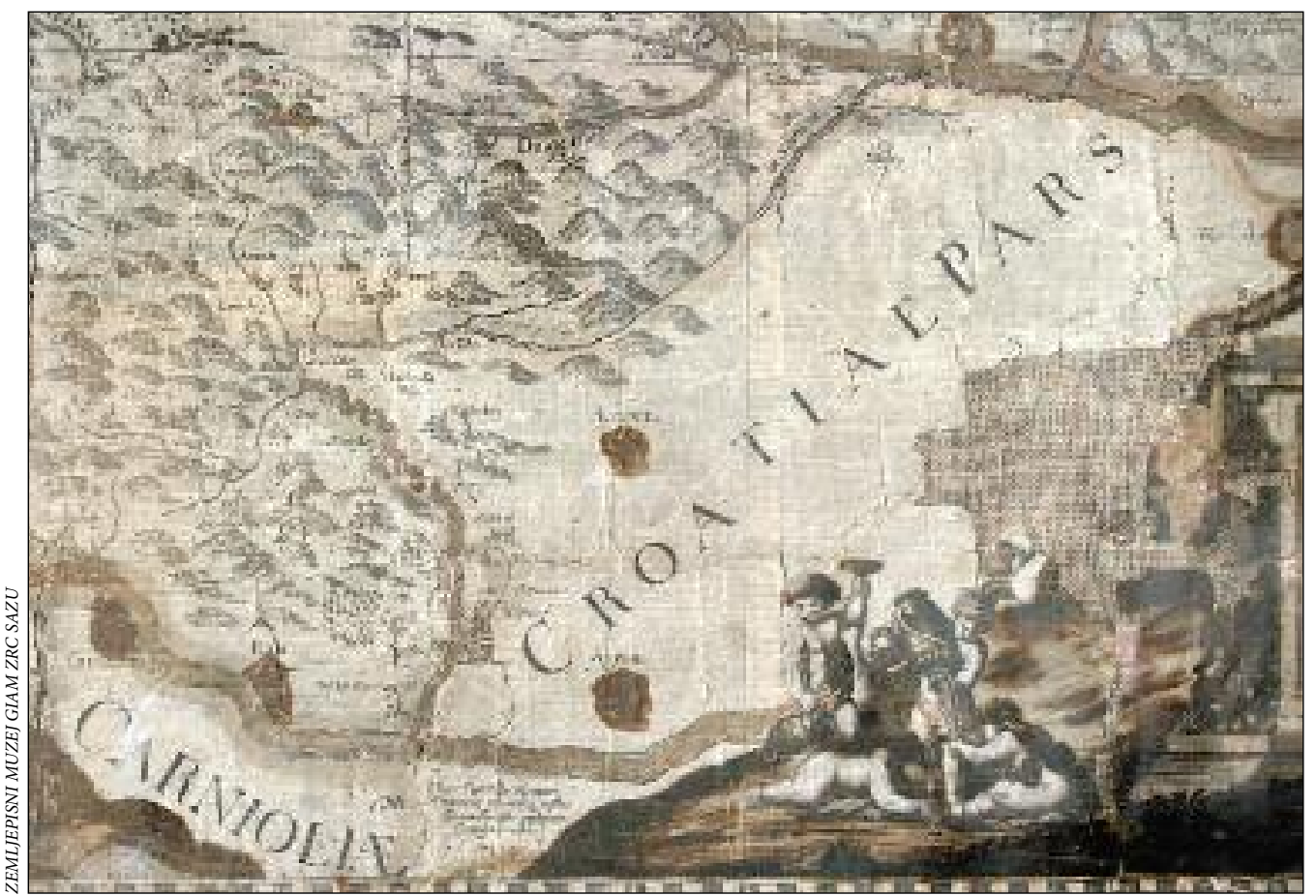

Slika 11: Izsek iz zemljevida Styriae Ducatus Fertilissimi Nova Geographica Descriptio Georga Matthäusa Vischerja iz leta 1678. 
- 'Novi geografski opis najplodovitejše vojvodine Štajerske' (Styriae Ducatus Fertilissimi Nova Geographica Descriptio) duhovnika in kartografa Georga Matthäusa Vischerja iz leta 1678, v merilu med 1:160.000 in $1: 174.000$. Zemljevid je sestavljen iz dvanajstih delov, skupaj pa meri približno $124 \times 136$ centimetrov. Zelo podrobno prikazuje ozemlje Štajerske, vizualni vtis pa dajejo zemljevidu bogate ilustracije in besedila, ki zapolnjujejo prostor zunaj kartografskega prikaza (slika 11).

- 'Slava vojvodine Kranjske' (Die Ehre deß Hertzogthums Crain ) polihistorja Janeza Vajkarda Valvasorja iz leta 1689. Delo je eno najpomembnejših znanstvenih del o Kranjski, v katerem so med drugim objavljeni zemljevidi in skice slovenskega ozemlja (slika 12).

- 'Horografski zemljevid vojvodine Kranjske' (Ducatus Carnioliae Tabula Chorographica) cistercijana Janeza Dizme Florjančiča iz leta 1744, v merilu približno 1:100.000. Gre za najkakovostnejši in najpopolnejši zemljevid Kranjske te dobe. Sestavlja ga dvanajst delov; velikost celotnega zemljevida je približno $180 \times 188$ centimetrov. Posebnosti zemljevida so v zgornji desni kot dodana veduta in načrt Ljubljane ter številni slikovni dodatki, ki poudarijo značilnosti Kranjske (slika 13).

- 'Specialni zemljevid vojvodine Kranjske' (Special-Karte des Herzogthums Krain), ki ga je med letoma 1844 in 1846 izdelal vsestranski naravoslovec Henrik Freyer. Zemljevid je sestavljen iz 16 listov velikosti $39 \times 30$ centimetrov. Merilo zemljevida, ki ima za podlago avstrijski generalštabni zemljevid iz leta 1834, je približno $1: 113.500$. Natisnjen je bil v takrat novi tehniki, v pet barvnem kamnotisku.

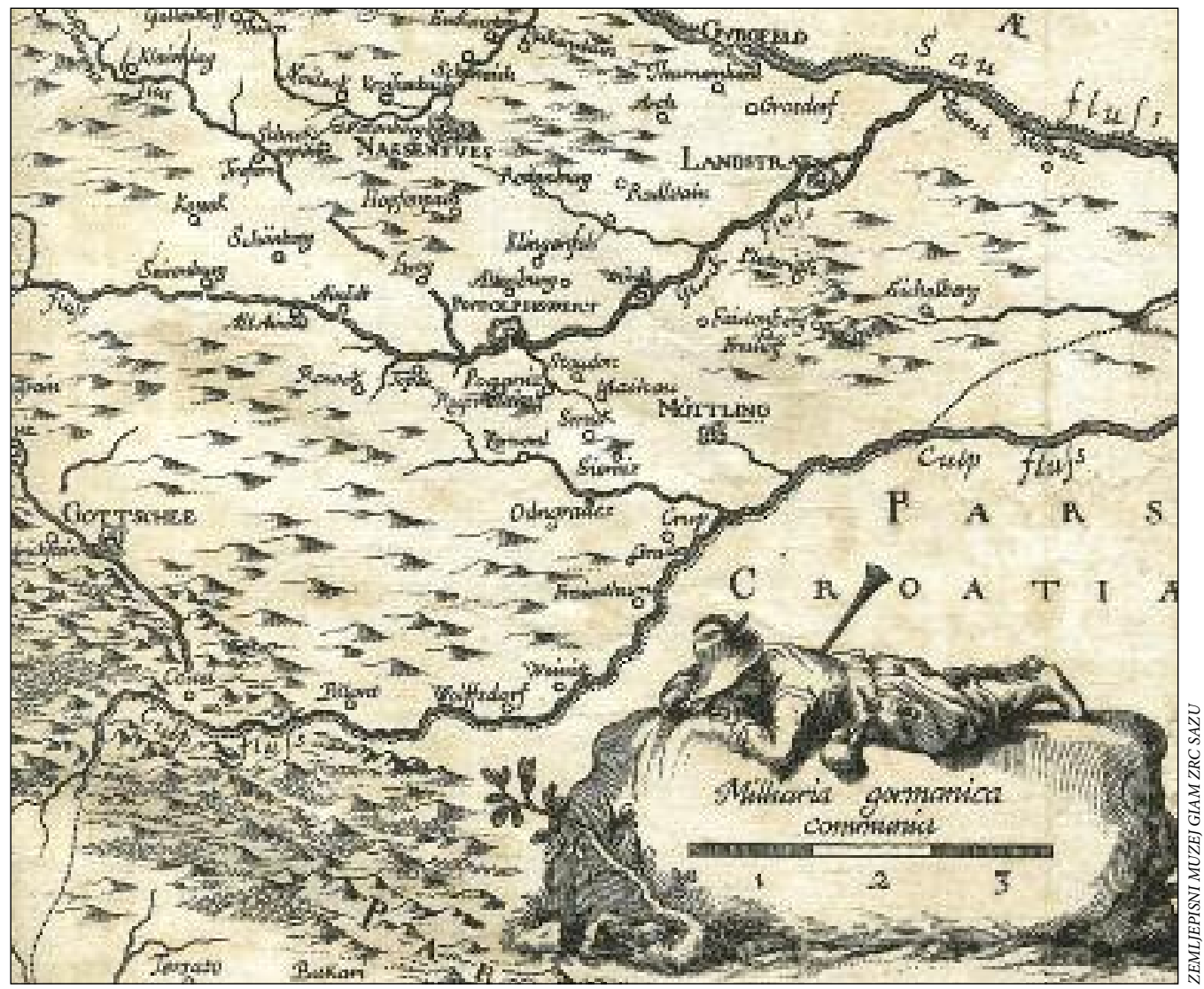

Slika 12: Izsek iz zemljevida Carniolia Karstia Histria et Windorum Marchia objavljenega v Slavi vojvodine Kranjske Janeza Vajkarda Valvasorja iz leta 1689. 


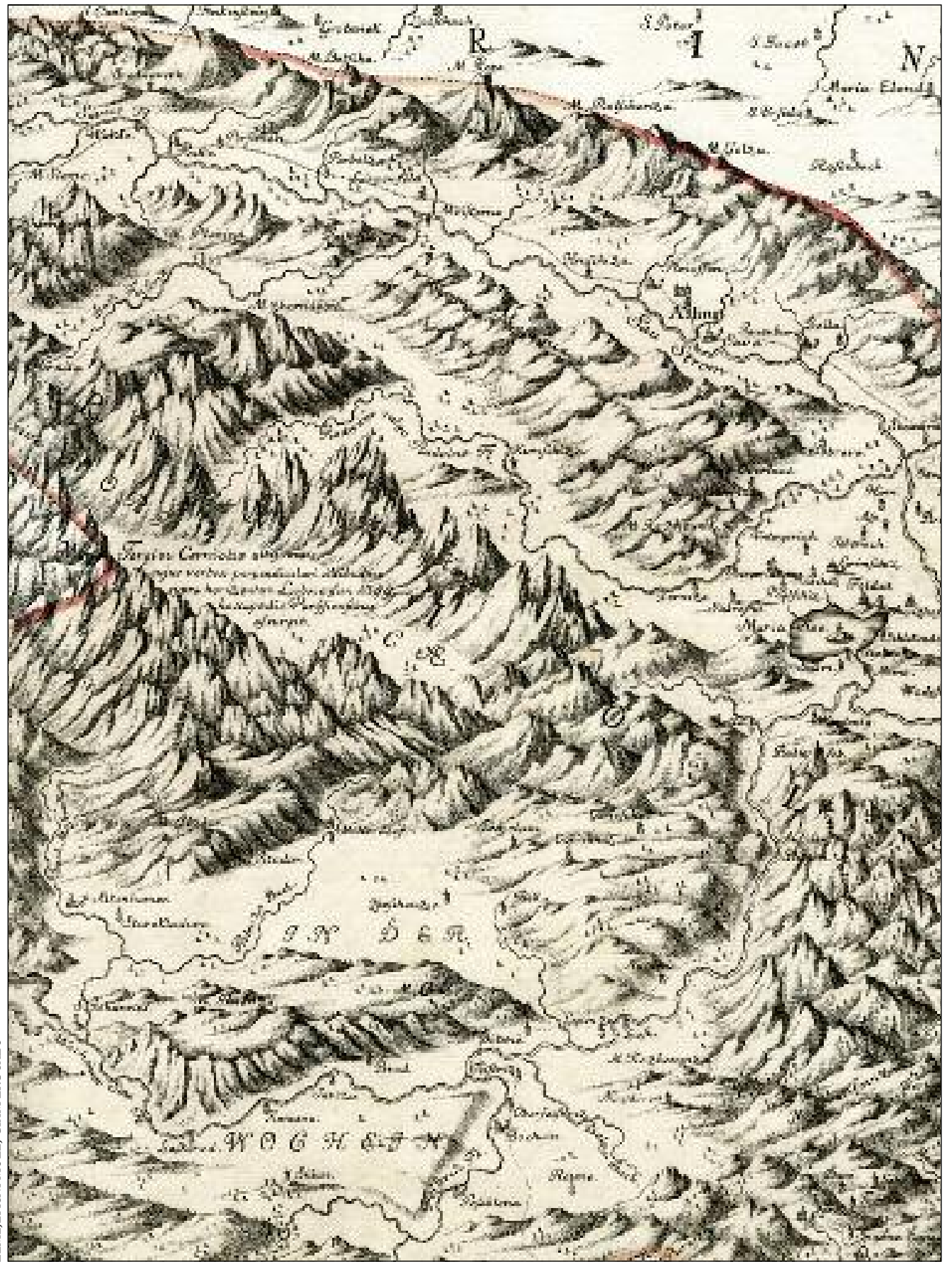

Slika 13: Izsek iz zemljevida Ducatus Carnioliae Tabula Chorographica Janeza Dizme Florjančiča iz leta 1744. 


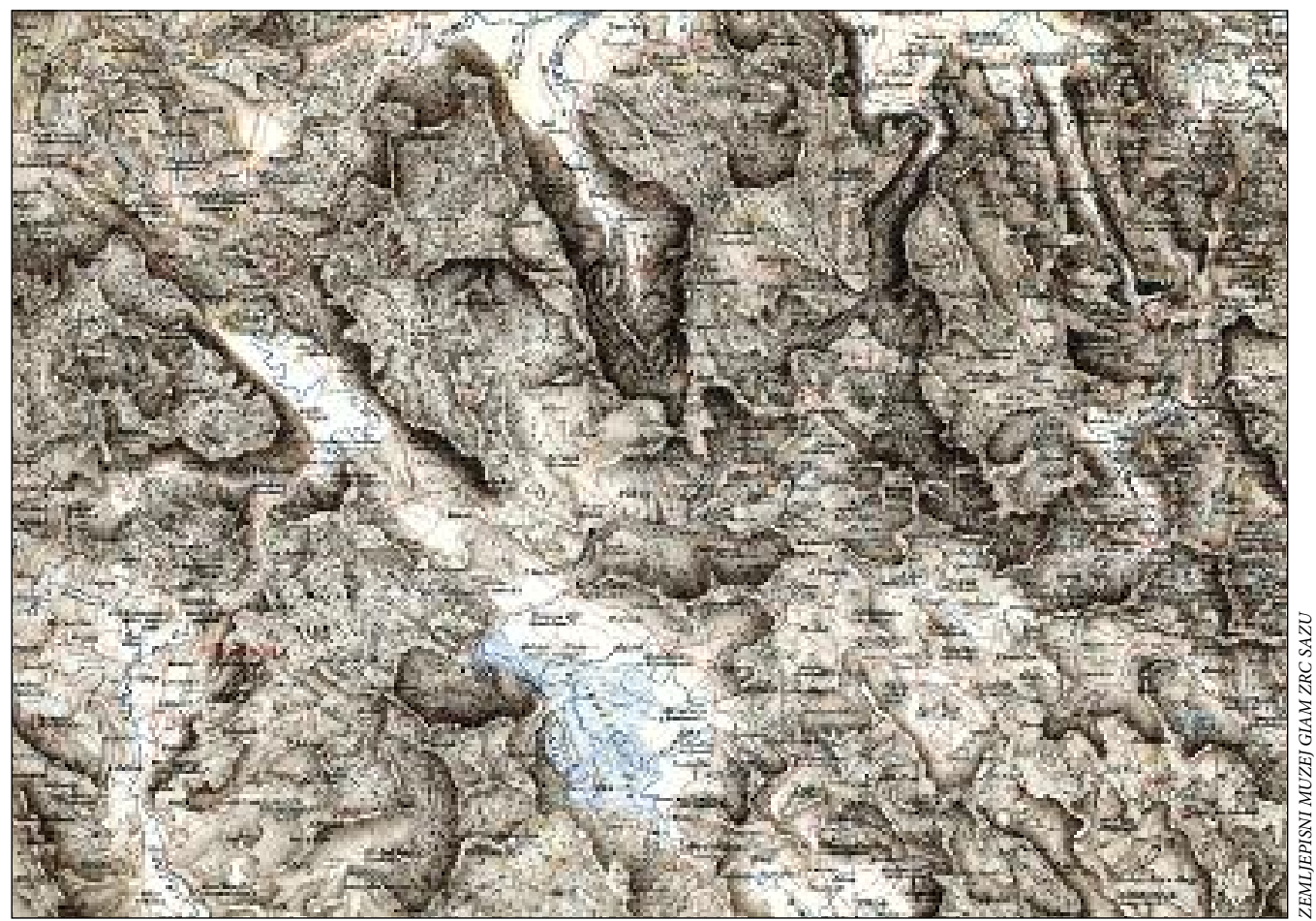

Slika 14: Izsek iz Specialnega zemljevida vojvodine Kranjske Henrika Freyerja, ki je bil izdelan med letoma 1844 in 1846.

Odlika zemljevida je izredno bogastvo slovenskih krajevnih imen; približno polovica imen ima dodano tudi nemško različico. Označena so nahajališča kamnin, rudnin in rudarskih objektov, ki so pojasnjena $\mathrm{v}$ legendi $\mathrm{z}$ naslovom Fosilije in montanistični znaki. Zemljevid predstavlja prvi slovenski stenski zemljevid, a z nemškim naslovom (slika 14).

- 'Zemljovid Slovenske dežele in pokrajin' pravnika Petra Kozlerja z letnico 1853, v merilu 1:576.000. Gre za zemljevid $\mathrm{z}$ dotlej najbolj natančno vrisano slovensko etnično mejo in $\mathrm{z}$ navedenimi izključno slovenskimi zemljepisnimi imeni (slika 15).

\section{Muzej in javnost}

"Muzeje pogosto dojemamo kakor zastražene trdnjave, ki čuvajo v prah odete predmete za steklenimi vitrinami. Dojemamo jih kot prostore, v katerih je treba biti tiho, a vselej tišino prelomi škripajoči pod.... To so predstave, ki si jih marsikdo prikliče v spomin ob misli na muzej in ki velikokrat odvrnejo ljudi od obiska muzeja. Tisti, ki so muzejem pripravljeni dati še eno priložnost, opazijo, da se je v njih marsikaj spremenilo. Sodobni muzeji so presegli poslanstvo svojega delovanja kot ustanove, ki skrbi zgolj za zbiranje, dokumentiranje, hranjenje in interpretiranje predmetov, ter se zavezali k družbeni odgovornosti... Kot javni prostori postajajo odprti za vse, ki želijo spoznavati dediščino in razvijati svoje znanje, razmišljanje in odnose s pomočjo muzejskih razstav in drugih muzejskih dogodkov ... " (Valič in Palaić 2014).

Takšen »drugačen muzej« (Drugačni ... 2015) je tudi Zemljepisni muzej, katerega poslanstvo ni le hramba in preučevanje geografke dediščine, pač pa tudi njena popularizacija (slika 16). Zato so v ok- 


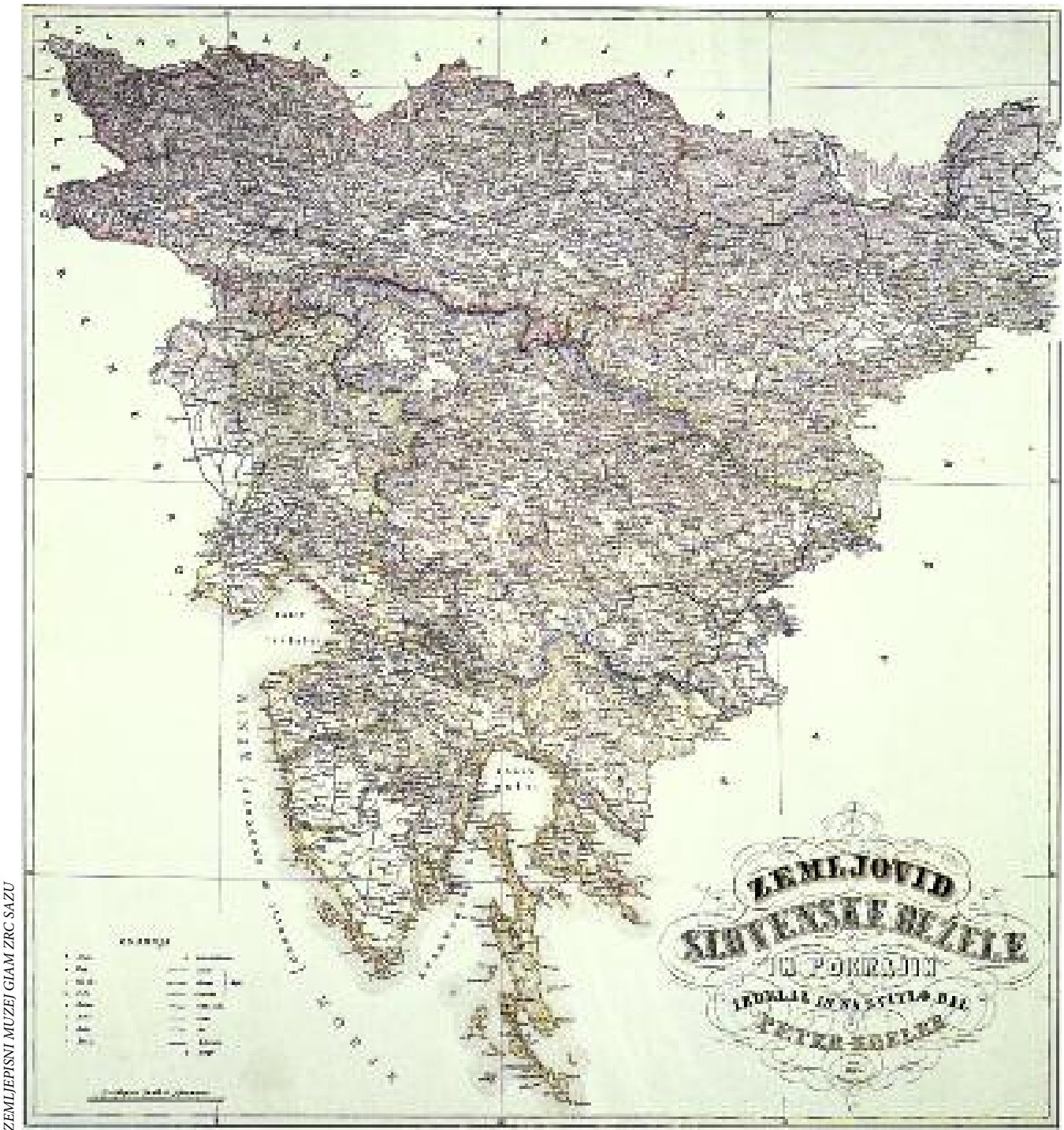

Slika 15: Zemljovid slovenske dežele in pokrajin Petera Kozlerja z letnico 1853.

viru muzeja organizirane številne razstave, delavnice, predavanja ali druge oblike izobraževanja za različne stopnje in vrste izobraževanja.

Muzej domuje v Ljubljani na dveh lokacijah. Na Gosposki ulici 13 sta arhiv in pisarna (slike 17-19), na Gosposki ulici 16 pa dvorana (prireditveni prostor) z razstaviščem (slika 20; Mihevc 1990). Vsi prostori so bili približno ob šestdesetletnici povsem prenovljeni ter sodobno opremljeni (Perko 2004, 107) in tako omogočajo primerno hrambo zgodovinskega kartografskega gradiva ter prijeten prireditveni ambient.

Manjši pisarniško-arhivski del omogoča raziskovalcem in obiskovalcem neposredno delo z arhivskim gradivom, omarne vitrine pa omogočajo tudi postavitev manjših razstav. 


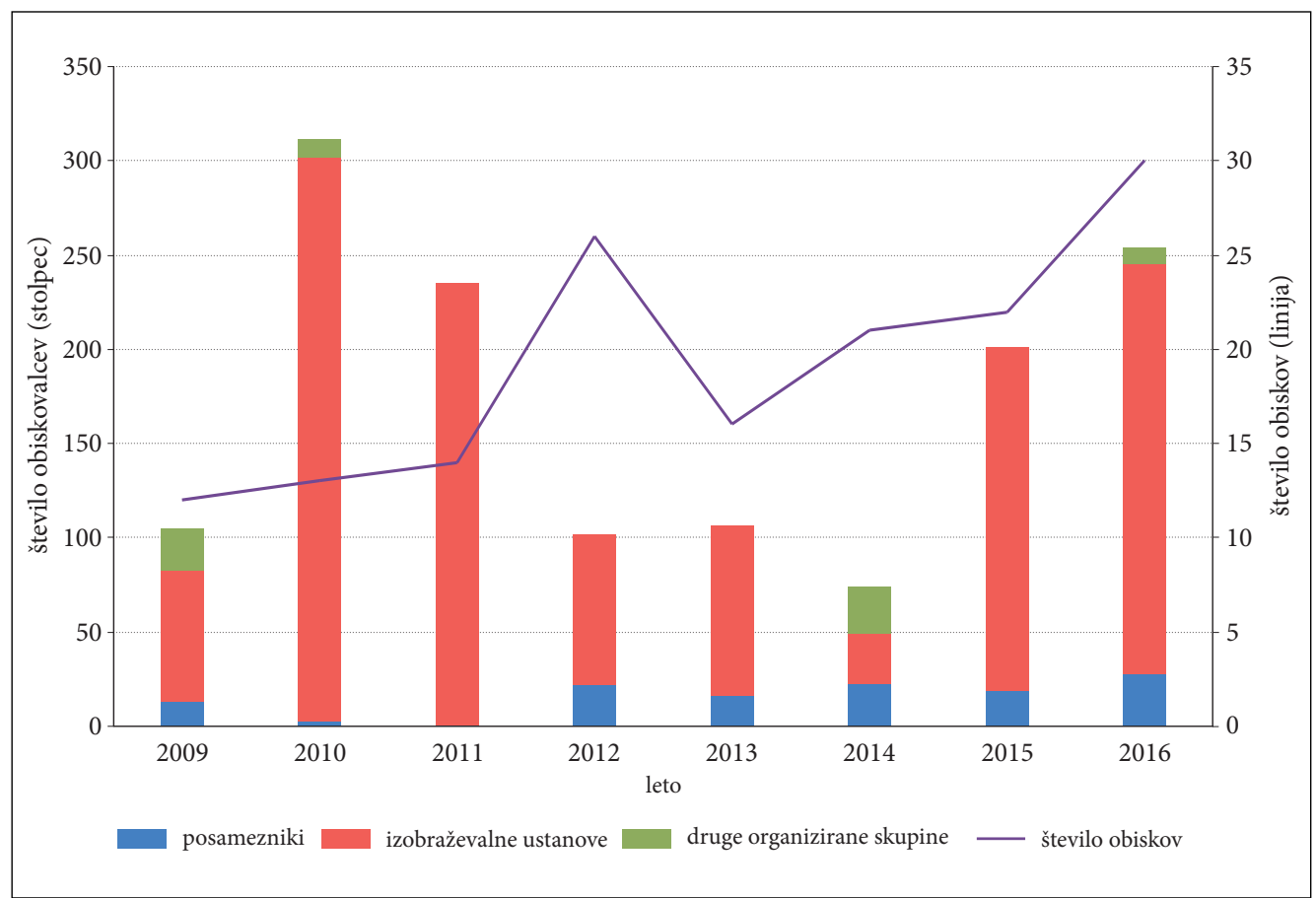

Slika 16: Število obiskov in obiskovalcev v Zemljepisnem muzeju po skupinah med letoma 2009 in 2016.

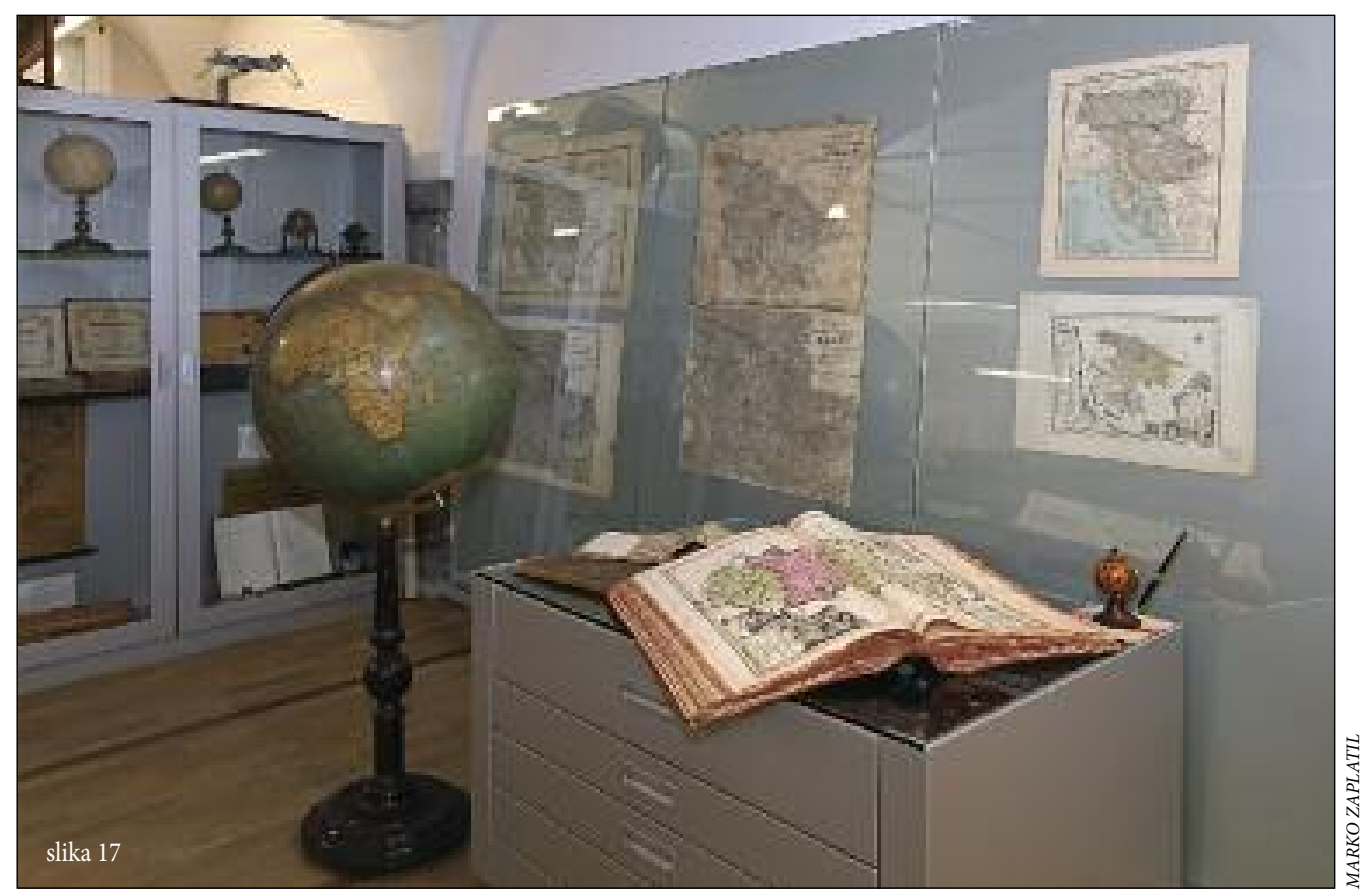




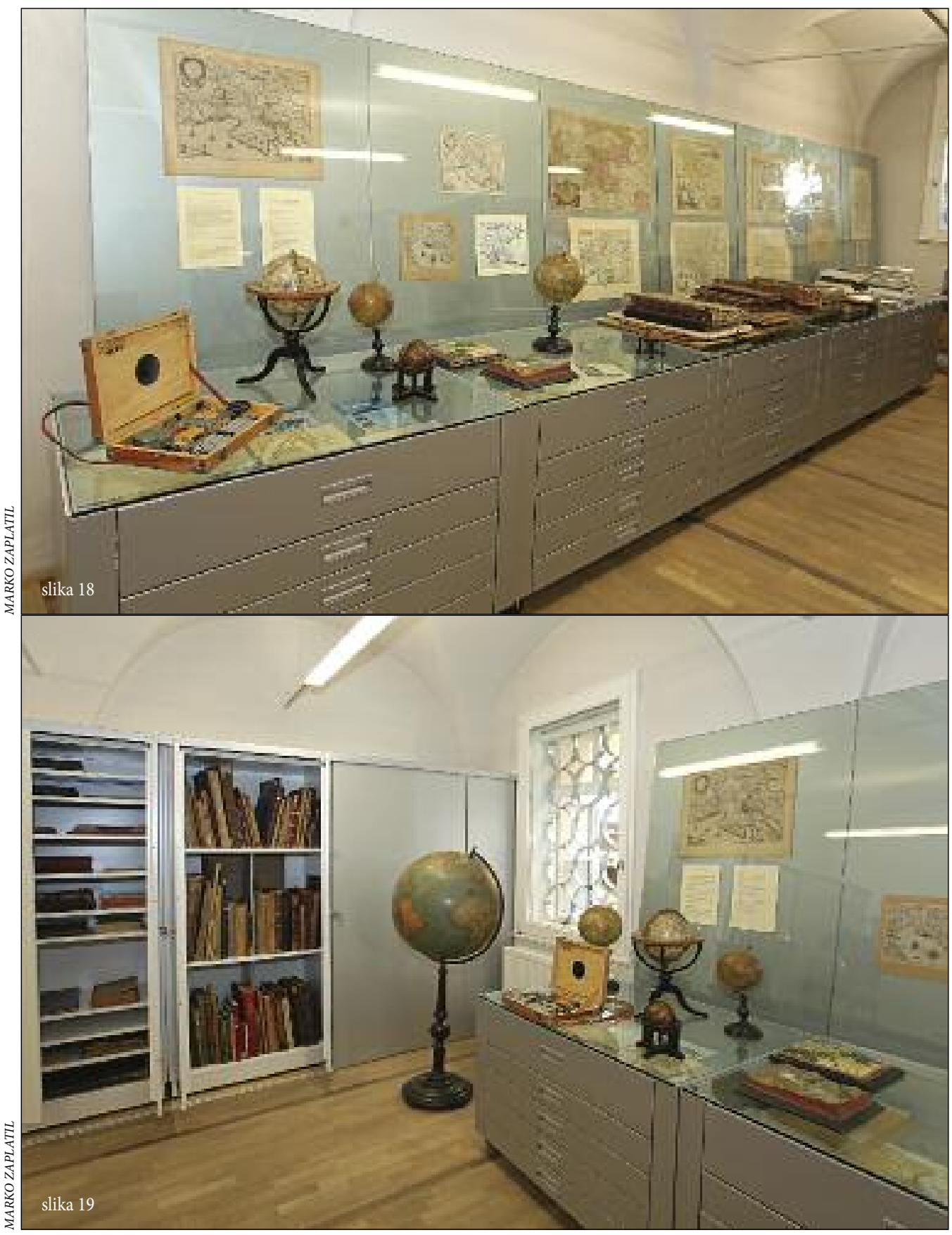

Slike 17-19: Arhiv in pisarna Zemljepisnega muzeja. V ognjevarnih omarah so shranjeni atlasi in druge dragocene knjige, $v$ predalčnikih zemljevidi, vitrine pa so namenjene razstavam. V letu 2016 je bila $v$ vitrinah predstavljena Kranjska na zemljevidih med 16. in 19. stoletjem (str. 112-113). 
Večji prireditveni prostor (slika 20) omogoča prireditve z do petdeset udeleženci (Perko 2004, 107) ter je zaradi lege v centru Ljubljane in svoje tehnične opremljenosti zelo priljubljen med zunanjimi uporabniki ter posledično v uporabi skoraj vse leto. Tako gosti številne okrogle mize, predstavitve knjižnih del (slika 21), predstavitve domačih in tujih projektov, doktoratov, predavanja za ciljne skupine, mednarodne in domače simpozije, srečanja društev ter potopisna in strokovna predavanja. Vsako leto se zvrsti več sto prireditev (slika 22). Razstavišče ob dvorani služi stalni predstavitvi inštitutskih publikacij. Za večje prireditve ima muzej na voljo tudi pokrit Atrij ZRC, ki je nekakšno velikansko preddverje arhiva muzeja, če v muzej vstopate prek vhoda na Novem trgu 2.
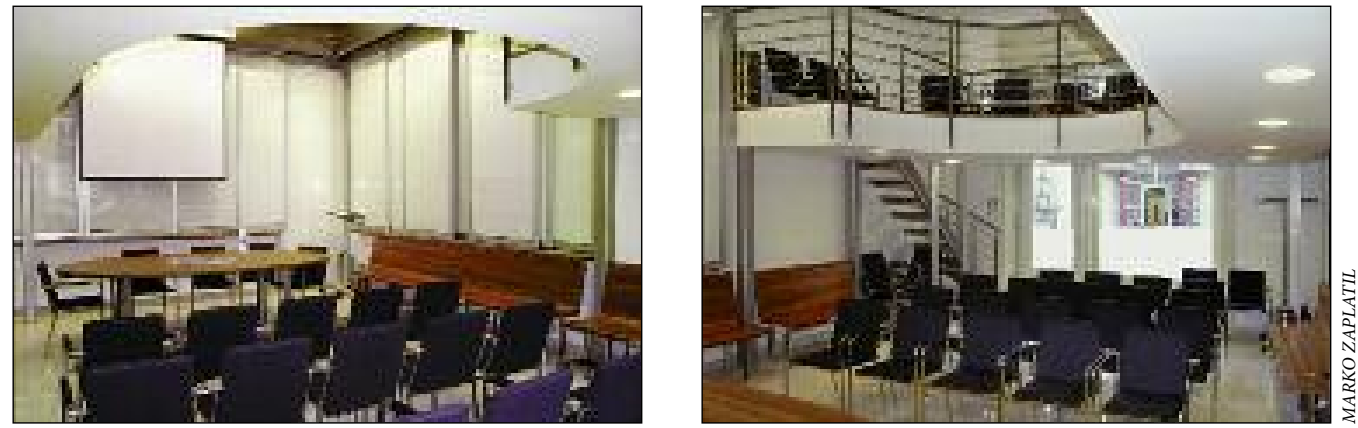

Slika 20: Dvorana Zemljepisnega muzeja omogoča prireditve $z$ do petdeset udeleženci.

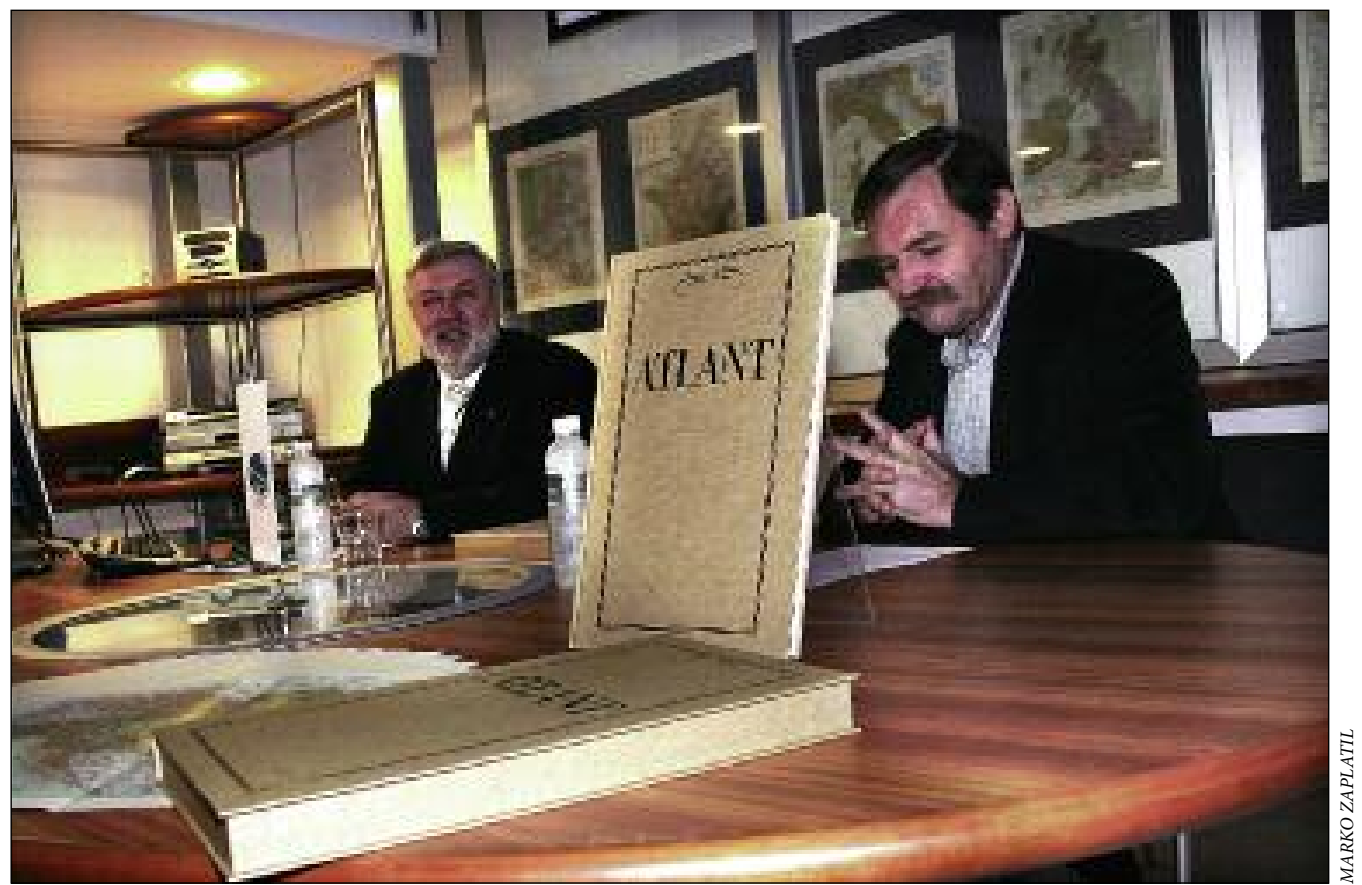

Slika 21: Tiskovna konferenca 28. septembra 2005 ob izdaji Atlanta - faksimila prvega svetovnega atlasa $v$ slovenskem jeziku, in odprtje razstave (zemljevidi na steni v ozadju), posvečene atlasu in Mateju Cigaletu (1819-1889), ki je atlas pripravil. Atlant sta predstavila (z leve): dr. Milan Orožen Adamič in dr. Vojislav Likar, takratni vodja Založbe ZRC, ki je publikacijo založila (Perko 2005, 143). 


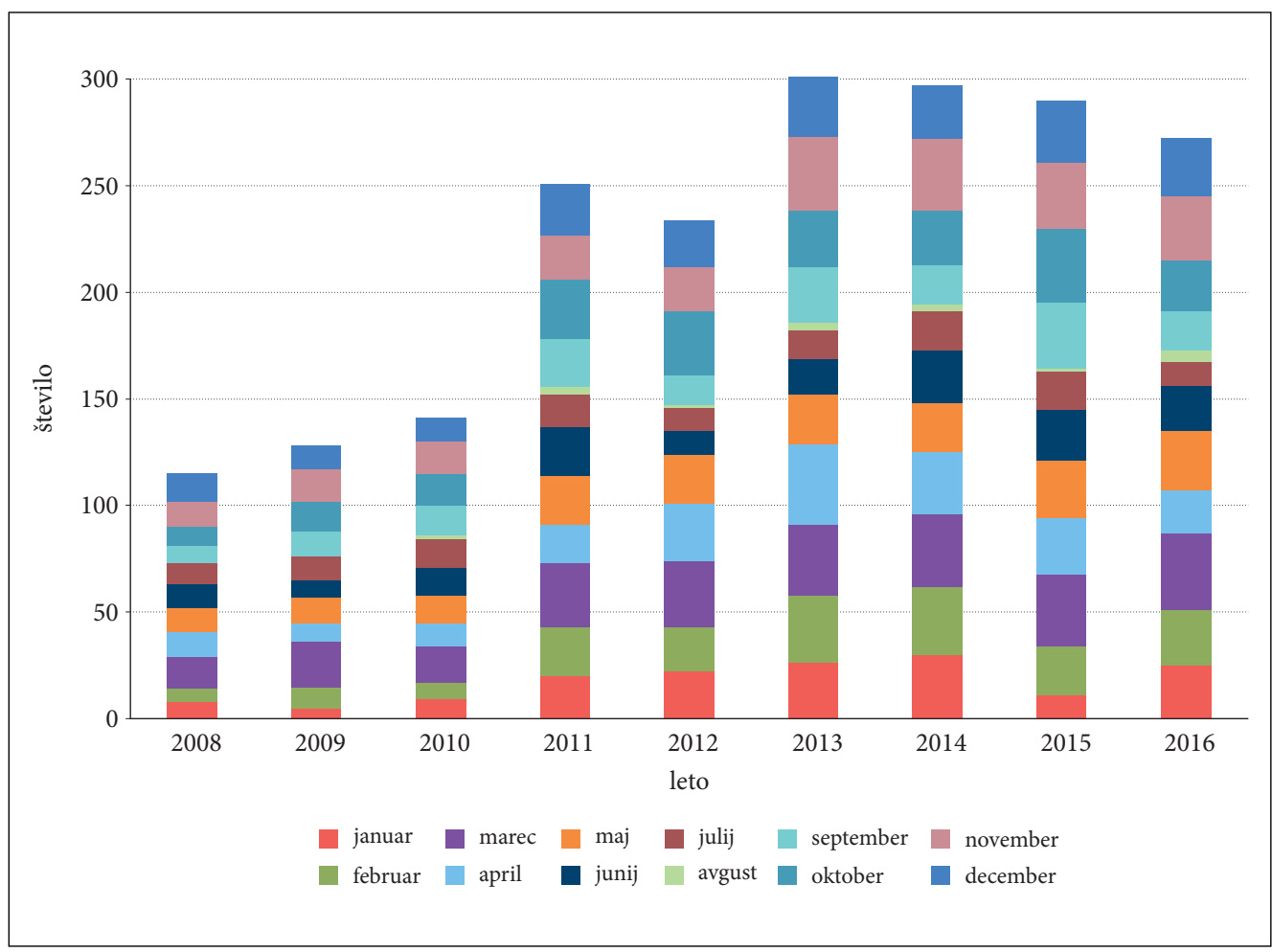

Slika 22: Število prireditev v dvorani Zemljepisnega muzeja med letoma 2008 in 2016.

Popularizacije ni brez medijev. Zemljepisni muzej se tako redno pojavlja v dnevnem časopisju (na primer Pavlovič 2014; Drugačni ... 2015, Bandur 2016), radiu in Facebooku (Geografski ... 2016), ima pa tudi svojo spletno stran (Zemljepisni ... 2016). Poleg znanstvenih objav (na primer Fridl in ostali 2005; Gašperič 2007; 2010; 2015; Bratec Mrvar in ostali 2011; Fridl in Šolar 2011; Gašperič, Orožen Adamič in Šumrada 2012) skrbi tudi za bolj poljudne in strokovne prispevke (na primer Gašperič in Zorn 2011; Gašperič 2013; 2016b).

\section{Sklep}

Obletnica Zemljepisnega muzeja sovpada z Mednarodnim letom zemljevida 2015-2016 (International Map Year; Hrastar 2015), katerega eden poglavitnih namenov je popularizacija zemljevidov. Mednarodno leto zemljevida »...predstavlja globalno praznovanje kart in njihove posebne vloge $v$ vsakdanjem življenju, predstavlja pa tudi priložnost za demonstracijo, spremljanje, učenje in spoznavanje procesa izdelave kart, uporabe kart in geografskih podatkov na splošno. Osnovne namene... lahko opišemo kot: približati karte vsej publiki (predvsem učencem) na globalni ravni; ponuditi priložnost za odkrivanje znanosti, povezanih s kartografijo; pokazati, kako vse so lahko karte uporabne v družbi ... (Mednarodno ... 2016).

S svojim poslanstvom Zemljepisni muzej Geografskega inštituta Antona Melika ZRC SAZU mednarodno leto zemljevida praznuje vsako leto. Kljub razvejani dejavnosti, bogatemu hranjenemu gradivu in dolgoletnemu delovanju pa je Zemljepisni muzej eden redkih muzejev nacionalnega pomena v Sloveniji, ki mu država ne dodeljuje finančnih sredstev neposredno prek Ministrstva za kulturo, 
kljub temu, da je bilo tako zapisano v Uredbi (1946) ob njegovi ustanovitvi. S tem je muzej finančno prepuščen samemu sebi oziroma ga finančno pokriva Geografski inštitut Antona Melika ZRC SAZU. Takšno stanje hromi njegovo še bolj poglobljeno delovanje na področju hrambe, preučevanja in popularizacije slovenske geografske dediščine.

\section{Viri in literatura}

About the Collections. Royal Geographical Society. London, 2016. Medmrežje: http://www.rgs.org/ OurWork/Collections/About+The+Collections/About+the+Collections.htm (14. 10. 2016).

Bandur, S. 2016: Kaj je zemljevid v času aplikacije google maps. Delo 58-121, 26. 5. 2016. Medmrežje: http://www.delo.si/prosti-cas/zanimivosti/kaj-je-zemljevid-v-casu-google-maps.html (14. 10.2016).

Bratec Mrvar, R., Birsak, L., Fridl, J., Kladnik, D., Kunaver, J. 2011: Kocenov srednješolski atlas kot didaktična prelomnica. Geografija Slovenije 22. Ljubljana.

Brečko Grubar, V., Koderman, M., Kovačič, G. 2016: 15 let Oddelka za geografijo Fakultete za humanistične študije Univerze na Primorskem. Geografski vestnik 88-1.

CartoMundi. Maison méditerranéenne des sciences de l'homme. Aix-en-Provence, 2016. Medmrežje: http://www.cartomundi.fr/site/ (14.10.2016).

Collections with Maps. Library of Congress. Washington, 2016. Medmrežje: https://www.loc.gov/maps/ collections/ (14.10.2016).

Dela. Medmrežje: http://revije.ff.uni-lj.si/Dela/issue/archive (14 10.2016).

Digitalna knjižnica Slovenije. Narodna in univerzitetna knjižnica. Ljubljana, 2016. Medmrežje: http://www.dlib.si (14.10.2016).

Drugačni muzeji: Zemljepisni muzej. Delo, 13.11.2015. Medmrežje: http://www.delo.si/kultura/ razno/drugacni-muzeji-zemljepisni-muzej.html (14. 10.2016).

Erhartič, B. 2014: Ohranjanje kulturne dediščine. Upravljanje območij s kulturno dediščino, CAPACities 2. Ljubljana.

Frajer, J., Geletič, J. 2011: Research of historical landscape by using old maps with focus to its positional accuracy. Dela 26. DOI: http://dx.doi.org/10.4312/dela.36.3.49-67

Frelih, M., Knez Račič, I., Miklič Cvek, L., Turk, J. 2009: Devetdeset let geografske knjižnice. Dela 32.

Fridl, J., Kladnik, D., Orožen Adamič, M., Perko, D., Urbanc, M. (ur.) 2005: Atlant. Ljubljana.

Fridl, J., Šolar, R. 2011: Vpliv razvoja kartografskih tehnik na podobe zemljevidov slovenskega ozemlja od 16. do 19. stoletja. Knjižnica 55-4.

Fuchs, R., Verburg, P. H., Clevers J. G. P. W., Herold, M. 2015: The potential of old maps and encyclopaedias for reconstructing historic European land cover/use change. Applied Geography 59. DOI: http://dx.doi.org/10.1016/j.apgeog.2015.02.013

Gaberc, S. 1999: Kartografska zbirka v piranskem pomorskem muzeju. Portorožan 9-5.

Gabrovšek, F., Ravbar, N. 2015: Editorial: 60 years of Acta Carsologica: past, present, future. Acta Carsologica 44-3. DOI: http://dx.doi.org/10.3986/ac.v44i3.4250

Gašperič, P. 2007: Kartografske upodobitve Slovenije skozi čas. Acta geographica Slovenica 47-2. DOI: http://dx.doi.org/10.3986/AGS47205

Gašperič, P. 2010: O Zemljevidu Ilirskih provinc avtorja Gaetana Palme iz leta 1812. Acta geographica Slovenica 50-2. DOI: http://dx.doi.org/10.3986/AGS50205

Gašperič, P. 2013: Kartografija v času Ilirskih provinc: primer branja starega zemljevida. Geografski obzornik 60-3.

Gašperič, P. 2015: Najstarejša kartografija - razvoj do antike. Geografski vestnik 87-2. DOI: http://dx.doi.org/ $10.3986 / G V 87206$

Gašperič, P. 2016a: Razvoj metod prikaza kartografskih elementov na starih zemljevidih ozemlja Slovenije. Doktorsko delo, Fakulteta za humanistične študije Univerze na Primorskem. Koper. 
Gašperič, P. 2016b: Stari zemljevidi slovenskega ozemlja. National Geographic Slovenija 11-10.

Gašperič, P., Orožen Adamič, M., Šumrada, J. 2012: Zemljevid Ilirskih provinc iz leta 1812. Ljubljana.

Gašperič, P., Zorn, M. 2011: Vzpeti svet na starih zemljevidih ozemlja Slovenije: zgodovinski oris slovenske planinske kartografije. Planinski vestnik 116-12.

Gašperič, P., Zorn, M. 2015: Sedem desetletij Zemljepisnega muzeja. Mohorjev koledar 2016. Celje.

Geoghegan, H. 2010: Museum geography: Exploring museums, collections and museum practice in the UK. Geography Compass 4-10. DOI: http://dx.doi.org/10.1111/j.1749-8198.2010.00391.x

Geografski inštitut Antona Melika ZRC SAZU. Medmrežje: https://www.facebook.com/GIAM.ZRC.SAZU/ (14. 10.2016).

Geografski vestnik. Medmrežje: http://zgs.zrc-sazu.si/gv (14. 10. 2016).

Geografski zbornik. Medmrežje: http://giam.zrc-sazu.si/en/strani/acta-geographicageografski-zbornik\#v (14. 10.2016).

Geographica Slovenica. Medmrežje: http:/giam.zrc-sazu.si/sl/strani/geographica-slovenica-0\#v (14.10.2016).

Globenmuseum. Österreichische Nationalbibliothek. Dunaj, 2016. Medmrežje: http://www.onb.ac.at/ globenmuseum.htm (14.10.2016).

Grafenauer, B. 1960: Struktura in tehnika zgodovinske vede: Uvod v študij zgodovine. Ljubljana.

Historical Maps of the Habsburg Empire. Mapire, 2016. Medmrežje: http://mapire.eu/en/ (14. 10. 2016). Horvat, U. 2013: Petdeset let geografije v Mariboru. Geografski obzornik 60-3.

Hrastar, T. 2015: Mednarodno leto zemljevidov. Geomix 22-1.

Hungarian Geographic Museum. Budimpešta, 2016. Medmrežje: http://www.foldrajzimuzeum.hu/ (14.10.2016).

Jenny, B., Hurni, L. 2011: Studying cartographic heritage: Analysis and visualization of geometric distortions. Computers and Graphics 35-2. DOI: http://dx.doi.org/10.1016/j.cag.2011.01.005

Jenny, B., Jenny, H., Hurni, L. 2009: Alte Karten als historische Quelle: wie lässt sich die geometrische Genauigkeit des Karteninhalts abschätzen? Geschichte und Informatik 16. DOI: http:/doi.org/ $10.5169 /$ seals-326532

Knez Račič, I. 2016: Ustni vir (17. 10. 2016). Knjižnica Oddelka za geografijo Filozofske fakultete Univerze v Ljubljani. Ljubljana.

Kušar, S. 2013: Geografski obzornik: preteklih 10 let. Geografski obzornik 60-3.

Maps and Atlases. Royal Geographical Society. London, 2016. Medmrežje: http://www.rgs.org/ OurWork/Collections/About+The+Collections/Maps+and+atlases.htm (14.10.2016).

Markovič, I. 1995: Pietro Coppo in dragocena kartografska zbirka v Piranu. Primorska srečanja 19-175.

Medmrežje 1: http://www.primorci.si/osebe/bogi\%C4\%87-mirko/1360/ (19.3.2015).

Medmrežje 2: http://www.arhiv.mk.gov.si/si/delovna_podrocja/kulturna_dediscina/premicna_kulturna_ dediscina/ (14.10.2016).

Medmrežje 3: http://www.nuk.uni-lj.si/nuk/organizacija/kartografska-zbirka (14.10. 2016).

Medmrežje 4: http://www.ukm.um.si/kartografska-zbirka (14.10. 2016).

Mednarodno leto kart. Medmrežje: https:/geonoviceslo.wordpress.com/tag/mednarodno-leto-kart/ (14. 10.2016).

Mihevc, B. 1993: Iz zbirke Zemljepisnega muzeja Slovenije. Geografski obzornik 40-1.

Mihevc, B. 1998: Slovenija na starejših zemljevidih. Geografski atlas Slovenije: Država v prostoru in času. Ljubljana.

Mihevc, B. 1990: Nova pridobitev Zemljepisnega muzeja Slovenije. Geografski obzornik 37, 3-4.

Mihevc, B. 1992: Katalog kartografskega gradiva 16., 17. in 18. stoletja v Sloveniji. Poročilo, Inštitut za geografijo Univerze v Ljubljani. Ljubljana.

Mokre, J. 2005: The Globe Museum of the Austrian National Library. Dunaj.

National Geographic Museum. National Geographic Society. Washington, 2016. Medmrežje: http://events.nationalgeographic.com/national-geographic-museum/ (14. 10.2016). 
Naylor, S., Hill, J. 2011: Museums. The SAGE Handbook of Geographical Knowledge. London. DOI: http://dx.doi.org/10.4135/9781446201091.n5

Old Maps Online. Medmrežje: http://www.oldmapsonline.org/ (14. 10.2016).

Pavlovič, L. 2014: Sporočila starih zemljevidov ozemlja Slovenije. Delo 56-263, 13. 11.2014. Medmrežje: http://www.delo.si/znanje/znanost/sporocila-starih-zemljevidov-ozemlja-slovenije.html (14.10.2016).

Perko, D. 2004: Obnovitev dvorane Zemljepisnega muzeja Geografskega inštituta Antona Melika ZRC SAZU. Geografski vestnik 76-2.

Perko, D. 2005: Razstava in tiskovna konferenca ob izidu publikacije Atlant. Geografski vestnik 77-2.

Perko, D. 2012: Uvodna beseda: Geografski inštitut in šestdesetletnica njegovega kartografskega oddelka. Zemljevid Ilirskih provinc iz leta 1812. Ljubljana.

Perko, D., Zorn, M. 2008: Zgodovina Geografskega vestnika. Geografski vestnik 80-2.

Perko, D., Zorn, M. 2016: Sedemdeset let raziskovanj na Geografskem inštitutu Antona Melika ZRC SAZU. Geografski vestnik 88-2. DOI: http://dx.doi.org/10.3986/GV88207

Petek, F., Bric, V., Rotar, T. 2004: Uporaba starih letalskih posnetkov pri ugotavljanju sprememb rabe tal. Geografski informacijski sistemi v Sloveniji 2003-2004. Ljubljana.

Petek, F., Fridl, J. 2004: Pretvarjanje listov zemljiško-katastrskega načrta v Gauss-Krügerjev koordinatni sistem. Geografski vestnik 76-2.

Petek, F., Urbanc, M. 2004: Franciscejski kataster kot ključ za razumevanje kulturne pokrajine v Sloveniji v 19. stoletju. Acta geographica Slovenica 44-1. DOI: http://dx.doi.org/10.3986/AGS44104

Potrdilo o opravljanju in vodenju muzejske in knjižničarske dejavnosti v času službovanja na Inštitutu za geografijo. Arhiv Geografskega inštituta Antona Melika ZRC SAZU. Ljubljana, 5. 4. 2004.

Prelovšek, M. 2007: Inštitut za raziskovanje krasa ZRC SAZU - 60 let kontinuiranega raziskovanja krasa. Geografski obzornik 54, 3-4.

Register nepremične kulturne dediščine. Ministrstvo za kulturo. Ljubljana, 2016. Medmrežje: http://giskd6s.situla.org/giskd/ (14.10.2016).

Reinhard, R. 1934: The Museum of Regional Geography in Leipzig. Geographical Review 24-2.

Resnik Planinc, T., Kušar, S. 2010: Devetdeset let Oddelka za geografijo Filozofske fakultete Univerze v Ljubljani. Dela 33.

Rumsey, D., Williams, M. 2002: Historical maps in GIS. Past Time, Past Place: GIS for History. Redlands. Semenov-Tian-Shansky, B. 1929: The Geographical Museum. Geographical Review 19-4.

Slukan Altić, M. 2003: Povijesna kartografija: kartografski izvori u povijesnim znanostima. Samobor.

Šolar, R. 2007: Kartografski in slikovni zakladi. Zakladi Narodne in univerzitetne knjižnice v Ljubljani. Ljubljana.

Šolar, R. 2016a: Map libraries - challenges for the future. e-Perimetron 11-2.

Šolar, R. 2016b: Ustni vir (17. 10.2016). Kartografska in slikovna zbirka Narodne in univerzitetne knjižnice. Ljubljana.

Štular, B. 2010: Jožefinski vojaški zemljevid kot vir za preučevanje preteklih pokrajin. Geografski vestnik 82-1.

Terčon, N. (ur.) 2001: Petrus Coppus fecit: de summa totius orbis. Piran.

Triglav, J. 2009: Geodetsko-katastrski fondi Arhiva Republike Slovenije. Geodetski vestnik 53-2.

Uredba vlade Ljudske republike Slovenije o ustanovitvi in ustroju Zemljepisnega muzeja Slovenije. Geografski vestnik 18. Ljubljana, 1946.

Valič, U., Palaić, T. 2014: Širjenje vloge muzejev in muzealcev: Dostopnost kulturne dediščine. Pogledi 5-11. Medmrežje: http://www.pogledi.si/mnenja/sirjenje-vloge-muzejev-muzealcev (14. 10. 2016).

Vobovnik-Avsenak, M. 1990: 45 let kartografske in slikovne zbirke NUK v Ljubljani. Knjižnica 34-4.

Vrišer, I. 1992a: Leban Vladimir. Enciklopedija Slovenije 6. Ljubljana.

Vrišer, I. 1992b: Uvod v geografijo. Ljubljana.

Zemljepisni muzej. Geografski inštitut Antona Melika ZRC SAZU. Ljubljana, 2016. Medmrežje: http://giam.zrc-sazu.si/sl/strani/zemljepisni-muzej\#v (14.10.2016). 
Zgodovina slovenskih muzejev. Skupnost muzejev Slovenije. Ljubljana, 2016. Medmrežje: http://www.smsmuzeji.si/C/Items/1015?cat=1 (14.10.2016).

Zorn, M. 2007: Jožefinski vojaški zemljevid kot geografski vir. Geografski vestnik 79-2.

Zorn, M., Ciglič, R. 2014: Nekaj novosti ... Geografski vestnik 86-2.

Zorn, M., Komac, B. 2010: Zgodovina znanstvene revije Acta geographica Slovenica. Acta geographica Slovenica 50-1. DOI: http://dx.doi.org/10.3986/AGS50101

Žagar, T., Radovan, D., Tič, K., Janežič, M., Musek, T., Šolar, R. 2010: Geoknjižnica na portalu Digitalne knjižnice Slovenije (dLib.si). Knjižničarske novice 20-11.

\section{Summary: Geographical heritage: seven decades of the Geographical Museum}

(translated by DEKS d. o. o.)

The year 2016 marks seven decades since the founding of the Geographical Museum at the at the Anton Melik Geographical Institute of the Research Centre of the Slovenian Academy of Sciences and Arts. It was established on May 7th, 1946. The museum receives, stores, and organizes cartographic, pictorial, and archival geographic material, prepares exhibitions, and also promotes the popularization of geography. It comprises seven collections: maps, atlases, globes, pictures, books, cartographic and geographic instruments, and statistical data. By keeping this kind of material, it is an important preserver of Slovenian geographical heritage.

Geographical museums started appearing in the first half of the twentieth century. One of the first ones was established in 1919 in the Soviet Union in present-day Saint Petersburg. Before this, rich cartographic collections were part of national museums and libraries, as they still are today. The largest collection of this kind is held by the Library of Congress in Washington, DC, which contains over 5.5 million maps, eighty thousand atlases, and five hundred globes.

The Geographical Museum has seven collections. The Map Collection contains maps with various content and scales dating from the sixteenth century to the present. Most of the material relates to Slovenian territory and neighboring countries. The Atlas Collection contains many rare examples by the best-known cartographers in the world and shows how the presentation of the world has developed. The Globe Collection contains globes of various dimensions and ages, as well as depictions of the constellations. The Picture Collection contains postcards and photos of Slovenian places and regions and also a small number of copperplate engravings. The Book Collection contains publications connected with geography, cartography, and history. The Cartographic and Geographic Instrument Collection contains instruments which were used by cartographers for producing »classic « maps before the introduction of digital cartography and geographical field tools. The Statistical Data Collection contains statistical material about Slovenia.

The Geographical Museum is of course not the only museum that contains Slovenian geographical heritage. The map collection in particular is complemented by the Map and Picture Collection at the National and University Library in Ljubljana, which also holds many maps from the sixteenth century onward. There is also a rich map collection with a tradition going back to the 1920s and containing works dating from the second half of the nineteenth century onward at the University of Ljubljana's Geography Department at the Faculty of Arts. Historical cartographic material is also held by other libraries, archives, and museums. The Digital Library of Slovenia (dLib.si) is an important publically accessible source for written and cartographic resources, featuring a »geo-library« or online accessible historical cartographic material from the National and University Library and certain other libraries.

Historical cartographic material is important because it is not only a means for the spatial presentation of features, but also a reliable document of the place, time, and social circumstances in which it was created. This material often contains information that is not recorded in any other sources (e.g., geo- 
graphical names, borders, roads, watercourses, and landforms). As a source, it is primarily used for historical geography and environmental history, especially in connection with changes in land use and the cultural landscape. Like all historical sources, cartographic sources must also be critically assessed because they may contain unintentional errors (e.g., due to unfamiliarity with an area or outdated information) or intentional errors (e.g., on military maps).

The important cartographic works for Slovenian territory held by the Geographical Museum include the following: Münster's version of Ptolemy's Geographia from 1552, Georg Matthäus Vischer's Styriae Ducatus Fertilissimi Nova Geographica Descriptio (A New Geographical Description of the Most Fertile Duchy of Styria, 1678), Janez Vajkard Valvasor's Die Ehre deß Hertzogthums Crain (The Glory of the Duchy of Carniola, 1689), Janez Dizma Florjančič's Ducatus Carnioliae Tabula Chorographica (Chorographic Map of the Duchy of Carniola, 1744), Henrik Freyer's Special-Karte des Herzogthums Krain (Special Map of the Duchy of Carniola, 1844-1846), and Peter Kosler's Zemljovid Slovenske dežele in pokrajin (Map of the Slovenian Land and Regions, 1853).

Despite its variegated activities, the rich material that it preserves, and its many years of operation, the Geographical Museum is one of the few museums of national significance in Slovenia that the state does not provide financial support to directly through the Ministry of Culture. Such a situation hinders more intense activity in preserving, studying, and popularizing Slovenian geographical heritage. 